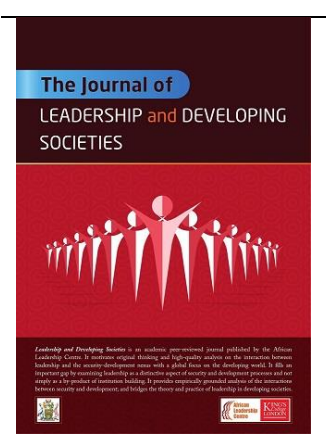

ARTICLE

\title{
Governing Dahiya: Interrogating the State in Beirut's Southern Suburbs
}

Fouad Gehad Marei ${ }^{a}$

Available online 23 December 2020

\begin{abstract}
Lebanon, a multi-confessional country with an established consociational democracy, is facing the threat of slipping into state failure as it grapples with its soaring political and economic crisis. The country's governing system has come under increased and perhaps unprecedented scrutiny since the outbreak of popular protests in 2019 as many accuse an oligarchic political and sectarian elite of subordinating the State to their private interests. Based on an empirical examination of the politics of post-war reconstruction in Beirut's southern suburbs, this article examines regimes of rule beyond the limitations of the seemingly dichotomous categories of State and nonstate. The empirical inquiry presented in this article argues for a state analysis that is less concerned with discerning and deciphering where the State begins (or ought to begin) and where its non-state other(s) end (or ought to end), but is concerned instead with unpacking the real and messy workings of government. Rather than relativising the weak-state thesis, this article seeks to extend and complicate our understanding of the State (in Lebanon and beyond) by locating regimes of rule within a broader, dynamically evolving social whole.
\end{abstract}

Keywords: multi-level governance; Hizbullah; Lebanon; non-state actors; reconstruction; Shia Islam; state theory; urban development

\section{INTRODUCTION}

The State ${ }^{1}$ has and continues to face increasing challenges in various regions of the world as its claim to the prerogatives and de jure rights of statehood are being eroded, both in times of insurgency as well as in peace. An example frequently cited in this regard is Lebanon, a country described as "one of the Middle East's chronically weak states." 2 Lebanon's state weakness is often juxtapositioned to Hizbullah, the most important

\footnotetext{
a Research Associate at the University of Birmingham Email: F.G.Marei@bham.ac.uk

${ }^{1}$ I deliberately alternate between 'state' and 'State' to make a semantic distinction between the State, capitalised and singularised, as a proper noun referring to a single entity that is discernible (at least as a theoretical abstract) and the state as a general-purpose reference used to specify a level of jurisdiction.

${ }^{2}$ Kamrava, Mehran (2014), 'Weak States in the Middle East,' in Fragile Politics: Weak States in the Greater Middle East, ed. by Mehran Kamrava (London: Hurst)
} 
Shii ${ }^{3}$ political movement in the country and arguably the most organised non-state actor in the Middle East. In this article, I examine the regimes of governance and rule that emerged in Beirut's southern suburbs after the 2006 war with Israel. Focusing on the politics of postwar reconstruction and urban rehabilitation, I interrogate emerging regimes of rule, asking: Who manages the formation and stewardship of the formal and informal rules that regulate the public realm? Where does governance take place? And how can a recognition of the complex nature of interactions between the State and non-/ extra-state actors contribute to state theory as well as to the practice of state- and institution building?

I examine these questions in the context of post-war reconstruction and the ensuing structures and practices of urban governance and rehabilitation in Beirut's southern suburbs, Dahiya. I map some of the actors involved in the reconstruction project and discuss some of the negotiations that were conducted and the strategies that were deployed, thus probing into the social and power relations latent in regimes of governance and rule in post-war Dahiya. I posit these reconfigurations of rule in Dahiya as reconfigurations of statehood itself. In so doing, I complicate state analysis, transcending the dominant weak-state and statewithering theses. Instead, I demonstrate that emerging regimes of governance and rule in contemporary Lebanon entail a transformation of both the State and its other(s), and thus result in the emergence and expansion of new state spaces. I argue that by examining evolutionary models of governance, we can decipher the fine-tuned workings of government and political power and unpack the politico-institutional configurations which 'mediate' stateness in Lebanon. This can contribute to comparative politics and social and state theory.

My analysis is based on research conducted over a five-year period from 2010 to 2015, during which I documented and analysed the politics of displacement, post-war reconstruction and on-site resettlement of

\footnotetext{
${ }^{3}$ I use Shii, the adjective form derived from Arabic (شيعي), to denote an attribute of a proper or common noun; e.g. Shii movement, Shii beliefs, and Shii person. I avoid using "[the] Shia," a commonplace expression used interchangeably as noun and adjective in English-language scholarship. Derived from the Arabic noun al-Shi'a (الثيعة), I only use Shia, singularised and capitalised, with a definite article, to refer to the [Shi'i] community, a constructed social category with a particular political implication.
}

Dahiya residents in the aftermath of the 2006 war. During the course of this period, my research focus shifted from state-society relations in post-war Dahiya, to the politics of local government and faith-based activism in Lebanon, and, more specifically, to Shii politics in Lebanon and beyond. This article is therefore informed by a mixture of research methods. In the period under examination, I conducted 25 interviews with central government and municipal officials, Hizbullah officials, urban planners and architects, and real estate developers. I also conducted over 40 interviews, focus groups and informal conversations with Dahiya residents during my long sojourns in Beirut. Furthermore, this research draws on a longue durée observation of urban transformations in Dahiya in light of the reconstruction effort, as well as an analysis of project documents, propaganda material, designs and maps I obtained from officials in Hizbullah's reconstruction agency, Waad, Dahiya municipalities, and United Nations agencies in Lebanon. Some of these documents are still not accessible publicly, despite the completion of the post-war reconstruction project in Dahiya in 2017.

This article is divided into four sections. First, I historically contextualise the Lebanese State and highlight the shortcomings of the dominant paradigms of state analysis in Lebanon. Second, I survey some of the theoretical propositions advanced by more recent scholarship on the State, showcasing the utility of concepts such as 'twilight institutions,' 'mediated stateness,' 'new state spaces,' and 'extended statehood'4. I argue that these theoretical approaches are better suited to account for evolutionary models of governance, enhancing our understanding of the State in relation to its extended and dynamically evolving social whole. Third, I present and document the case of post-war reconstruction and urban rehabilitation in Beirut's southern suburbs. I discuss the complex articulations of the regimes of rule that emerged in Dahiya since 2006 and probe into some of the social relations latent in these configurations of power. I

\footnotetext{
${ }^{4}$ On 'extended statehood,' see Bachmann, Olaf, introduction to this special issue. See also Bachmann, Olaf, Funmi Olonisakin, and Fouad G. Marei (2020), 'Revisiting Governance: Extended Statehood in Africa and Beyond', in Was es (heute) heißt, Soldat zu sein, ed. by Gerhard Kümmel (Baden-Baden: Nomos), pp. 145-169
} 
conclude with some conceptual reflections on the evolutionary models of governance in Lebanon, positioning my propositions in conversation with wider theorisations of the State.

\section{THE STATE OF LEBANON}

Since the founding of the modern state in Lebanon, consociational power-sharing along confessional lines, state minimalism, and freewheeling capitalism have been the pillars upon which the political system is premised. This arrangement consolidated subnational actors at the local, subnational and national levels of government, while also organising and orienting nonstate actors in relation to one another and the State. This model of government stood in queer contrast to state formation and state-society relations in much of the postcolonial global South and an outlandish exception to state-building projects in the Middle East. ${ }^{5}$ Impressively, the Lebanese political system proved resilient to twentieth-century étatism, resisting few ambitious attempts at consolidating state power, at strengthening the military and security establishments, and at building the 'strong' institutions of the interventionist Weberian-Westphalian state. ${ }^{6}$

\footnotetext{
${ }^{5}$ Nazih Ayubi's neo-Marxist study of state formation in the Arab world distinguishes between the so-called thawra ('revolution') and tharwa ('wealth') states. He argues that state formation in thawra polities relied more heavily on institution building and social engineering endeavours as opposed to the mobilisation of communitarian loyalties and forms of government by thawra states, which also rely heavily on rentierism. Ayubi's analysis, which explicitly excludes Lebanon, demonstrates how Lebanon diverges from the two categories of Arab states. See Ayubi, Nazih (1996), OverStating the Arab State: Politics and Society in the Middle East. (New York: I.B. Tauris)

${ }^{6}$ The most ambitious state-building project in Lebanon took place during the regimes of General Fouad Chehab (19581964) and his heir, Elias Sarkis (1976-1982). Chehab is credited for the initiation of institutional reforms and development projects, vehemently opposed to the established politicoeconomic elite. See Salibi, Kamal (1966), 'Lebanon under Fuad Chehab 1958-1964,' Middle Eastern Studies, 2 (3), pp. 211-226; Tonta, Rachela (2009), 'Why the Chehabist State Failed: The State-in-Society Approach,' Hemispheres: Studies on Cultures and Societies, 24, pp. 91-104; and Malsagne, Stéphane (2011), Fouad Chéhab: Une figure oubliée de l'histoire libanaise (Paris: Karthala)

${ }^{7}$ Nader Hashemi and Dany Postel propose the notion of sectarianisation, denoting "an active process [...] that involves the mobilisation of popular sentiments around particular identity markers." They juxtaposition this to sectarianism,
}

The Lebanese political order collapsed in 1975 as the country descended into civil war. While Lebanon's extremely complex fifteen-year war was not sectarian at root, it nonetheless expedited the 'sectarianisation' of society. ${ }^{7}$ Emerging from war, Lebanon installed a reformed version of its pre-war system. The Taif Agreement, which ended the civil war, considered the abrogation of political sectarianism a national priority, without providing any timeframe for doing so. ${ }^{8}$ Pending this abrogation, the Agreement consigned Lebanon to an "imaginary waiting room of history." ${ }^{9}$ Meanwhile, the agreement lay the foundations of Lebanon's Second Republic, transforming the Lebanese political system from a presidential to a parliamentary democracy. A significant slice of the executive powers previously concentrated in the office of the President of the Republic (which is exclusively held by a Maronite) ${ }^{10}$ was shifted to the Council of Ministers as a collective body. Moreover, the powers to elect the President of the Republic, form government, and nominate the Prime Minister were shifted to the Council of Deputies as a collective body. The Taif Agreement reformed the personalistic and distributive (muhāșşa) order, establishing parity between Muslims and Christians as

which "implies a static given, a trans-historical force." See Hashemi, Nader, and Dany Postel, (2017), 'Sectarianization: Mapping the New Politics of the Middle East,' The Review of Faith and International Affairs, 15 (3), pp. 3. In the context of the Lebanese civil war, sectarianisation describes how key belligerents of the civil war "manipulated and constructed ethnoreligious identities, typically through acts of extreme violence, to cleave society along communal lines." See Nagle, John and Mary-Alice Clancy (2019), 'Power-Sharing After Civil War: Thirty Years Since Lebanon's Taif Agreement,' Nationalism and Ethnic Politics, 25 (1), pp. 2

${ }^{8}$ Article G of Section II of the Taif Accord states that: "Abolishing political sectarianism is a fundamental national objective." The agreement was signed in the Saudi Arabian city of Taif on 22nd of October 1989 and ratified by the Lebanese Parliament (in exile) on $4^{\text {th }}$ of November ${ }^{9}$ Chakrabarty, Dipesh (2008 [2000]), Provincializing Europe: Postcolonial Thought and Historical Difference. (Princeton: Princeton University Press)

${ }^{10}$ Maronites are an ethnoreligious Christian group living in Lebanon. A large Maronite diaspora lives in the United States, Canada and Australia. The defining cultural characteristic of the Maronites is membership of the Maronite Church, an Eastern church in full communion with the Catholic See. See Stokes, Jamie (ed.), Encyclopedia of the Peoples of Africa and the Middle East (New York: Facts on File. An Imprint of Infobase), pp. 446-447 
well as between Sunnis and Shiis. ${ }^{11}$ The Agreement also enshrined the troika, whereby the three presidencies (i.e. of the republic, the government and the legislature) are allocated according to confessional affiliation: a Maronite president, a Sunni prime minister, and a Shii speaker of the parliament. ${ }^{12}$ In other words, rather than introducing systemic changes, the Agreement addressed the failures of the pre-war order by accommodating the new political forces and the balance of power that emerged during the civil war. This had the effect of gradually pacifying and re/integrating previously marginalised groups, the parvenu bourgeoisie and other political forces with a professed anti-systemic agenda into the post-war political order. ${ }^{13}$ Consociational power-sharing was reinstituted at all levels of government, inter alia, the judiciary, the security and armed forces, education, and almost all levels of civil service and the public sector. In short, the post-war order can be described as an 'upgrade' in a long lineage of power-sharing pacts dating back to 1840 . It renewed the country's commitment to the diffusion of power amongst sectarian actors, consolidating their authority at the subnational levels of government; seemingly, at the expense of the State.

An integral component of the post-war order was the adoption of institutional designs and practices shaped by the precepts of the liberal peace, a post-war settlement foregrounding the role of civil society, free markets and global aid-economy actors as the antidote to prevent future wars. ${ }^{14}$ It emphasised 'partnership' between state and non-/quasi-state actors, and evoked 'the community' as a stakeholder in peacebuilding and governance. Institutional design in post-war Lebanon was also heavily influenced by global transformations occurring under the rubric of neoliberalisation and the maxims of good governance. Of course, institutional designs and governance reforms are not immutable, but contingent on local and historical configurations of power. For example, I have argued elsewhere that, in the context of Lebanese communities and geographies where Hizbullah is the dominant political actor, processes of state rescaling and reordering of statesociety relations are "sequestered and layered by the combative encounter between" a Hizbullah project in "a state of perpetual defiance to U.S.-led politics of hegemony" and models of governance and development associated with neoliberal globalisation. ${ }^{15}$

The Although inspired by the maxims of Westerndominated international organisations and regimes of rule, Lebanon's post-war order paradoxically provided the institutional and political-legal infrastructure for the so-called 'Golden Formula' underpinning the relationship between the State and Hizbullah, the nonstate armed resistance group often reduced to its antiWestern inclinations. According to this Golden Formula, the army, 'the People,' and Hizbullah are together responsible for protecting Lebanon from foreign aggression. ${ }^{16}$ The dictum has been a defining pillar of Lebanon's national defence strategy, especially vis-à-vis Israel and, more recently, against the Islamic State in war-torn neighbouring Syria. However, the essence of this dictum extends into civilian life, constituting an

and inequalities. See, e.g., Makdisi, Samir, and Marcus Marktanner (2009), 'Trapped By Consociationalism: The Case of Lebanon,' Topics in Middle Eastern and North African Economies, 11, pp. 1-15; Fakhoury, Tamirace (2014), 'Debating Lebanon's Power-Sharing Model: An Opportunity or an Impasse for Democratization Studies in the Middle East?,' The Arab Studies Journal, 22 (1): pp. 230-255

${ }^{14}$ Richmond, Oliver P. (2005), The Transformation of Peace. (London: Palgrave); Richmond, Oliver P. (2006), 'The problem of peace: understanding the 'liberal peace', Conflict, Security \& Development, 6 (3), pp. 291-314

${ }^{15}$ Marei, Fouad Gehad, et. al. (2018) 'Interventions on the Politics of Governing the "Ungovernable", 'Political Geography, 67, pp. 181

${ }^{16}$ The Golden Formula (al-Mu'ādala al-Thahabiya) of ArmyPeople-Resistance is enshrined in Ministerial Declarations and in statements by Hizbullah leaders, top-echelon army officials and Lebanese politicians from across the political spectrum 
increasingly salient maxim and inviting political actors from across the political spectrum to assume responsibilities of civilian government, development strategy, and crisis response. According to this model, the State, non-/extra-state actors, and 'the community' exercise together the de jure prerogatives of the State.

\subsection{The state 'as it ought to be': Theorising Lebanon's 'weak state'}

Practitioners and scholars of Lebanese politics have typically condemned its State for its failure to meet the Weberian-Westphalian standards of a modern State. The weak-state thesis draws on the works of scholars preoccupied with recounting the many ways in which the Lebanese state 'fails' to meet criteria inspired by Max Weber's epoch-making definition of the modern State. Among these failures, scholars cite the Lebanese state's inability to claim a monopoly over legitimate physical violence within a particular territory, a key precept of Weber's model, 17 to define and defend its borders, to maintain territorial integrity and jurisdiction, to enact and implement one law for all citizens, and to regulate 'states of exception'.

In popular discourse, many Lebanese question the presence of their State, bemoaning its inability to provide basic infrastructure, public services and a sense of order. This is indicated by the commonplace exclamation of protest, wayn al-dawla? ("where is the State?"), which Joanne Randa Nucho discusses in her

\footnotetext{
${ }^{17}$ Weber, Max (2004 [1919]), The Vocation Lectures (Indianapolis: Hackett Publishing), pp. 33

${ }^{18}$ Nucho, Joanne Randa (2016), Everyday Sectarianism in Urban Lebanon: Infrastructures, Public Services, and Power (Princeton: Princeton University Press).

${ }^{19}$ Malaeb, Bilal (2018), State Fragility in Lebanon: Proximate Causes and Sources of Resilience (London/Oxford: LSE-Oxford Commission on State Fragility, Growth and Development), pp. 4

${ }^{20}$ The Fund for Peace (2015), Fragile States Index 2015. (Washington D.C.: The Fund for Peace)

${ }^{21}$ Mann, Michael (1984), "The Autonomous Power of the State: Its Origins, Mechanisms and Results," European Journal of Sociology, 25 (2), 185-213; Migdal, Joel (1988), Strong Societies and Weak States: State-Society Relations and State Capabilities in the Third World (Princeton: Princeton University Press); and Migdal, Joel (2001), State in Society: Studying How States and Societies Transform and Constitute One Another (New York: Cambridge University Press), pp. 48-49

22 Scholarship on early-modern Mount Lebanon emphasise the role of colonial political and economic interests in the emergence of modern Lebanon. See, for example, Fawaz,
}

ethnography of everyday sectarianism in Lebanon. ${ }^{18}$ Echoing similar sentiments, policy experts (who have often praised Lebanon for its reliance on partnerships with the private-sector and global aid providers) have also noted that the Lebanese state is "regressing into fragility"19 and warned that Lebanon is at "high risk" of state failure. ${ }^{20}$

These analyses are premised on two interrelated critiques: a Weberian critique of the Lebanese state's position vis-à-vis non-state actors domestically, and a Westphalian critique of its weakness vis-à-vis external actors. Together, they portray Lebanon as a weak state which lacks the infrastructural power to penetrate society and impose its dominance. It is thus seen as a State that is unable to ensure its autonomy or effect desirable change. ${ }^{21}$ Drawing on a familiar litany of tropes evoked to diagnose state weakness in Lebanon, these analyses point out that Lebanon was artificially carved out according to imperial designs and colonial interest ${ }^{22}$ and that is lacks a unifying historical fiction. ${ }^{23}$ A consequence of state weakness and social fragmentation is that a plethora of subnational non-state actors and sectarian institutions, as well as to sectarian strongmen (zu'ama al- țawa'ifif) and the political parties that represent them (known collectively by their critics as ahzāb al-șulta [the parties of political system]) 'capture' the State from below and undermine its authority. ${ }^{24}$ Meanwhile, foreign powers are free to meddle in the country's internal affairs.

Leila T. (1983), Merchants and Migrants in Nineteenth Century Beirut (Cambridge: Harvard University Press); Gates, Caroline (1989), 'The Historical Role of Political Economy in the Development of Modern Lebanon, Papers on Lebanon (Oxford: Centre for Lebanese Studies); and Gates, Caroline (1998), The Merchant Republic of Lebanon: The Rise of an Open Economy (Oxford: Centre for Lebanese Studies)

${ }^{23}$ See, for example, Salibi, Kamal (2003), A House of Many Mansions: The History of Lebanon Reconsidered (New York: I.B. Tauris)

${ }^{24}$ Much of the scholarship on the politics of Lebanon has been preoccupied with clientelism, 'primordial' loyalties, and the power of the $z u^{\prime} a m a$ vis-à-vis the State. See, for example, Khalaf, Samir (1977), 'Changing forms of political patronage in Lebanon,' in Patrons and Clients in Mediterranean Societies, ed. by Ernest Gellner and John Waterbury (London: Duckworth), pp. 185-205; Johnson, Michael (1986), Class and Client in Beirut: The Sunni Muslim Community and the Lebanese State (Reading: Ithaca); and Cammett, Melani, and Sukriti Issar (2010), 'Bricks and Mortar Clientelism. Sectarianism and the Logics of Welfare Allocation in Lebanon,' World Politics 62 (3), pp. 381-421 
Amongst the most extensively cited non-state actors accused of undermining the State in Lebanon is Hizbullah. The Islamic resistance movement and Shii political party emerged during the Lebanese civil war of 1975-1990 and against the backdrop of Israel's repeated invasions of Lebanon in the 1970s and 1980s. The 'Party of God' capitalised on the militant activism of a coterie of junior seminarians politicised and radicalised during the crackdown on Shii political activisits in Iraq and the revolutionary fervour accompanying the Islamic Revolution in Iran. ${ }^{25}$ The party also inherited a considerable network of wartime community- and faithbased welfare organisations. Throughout the civil war and beyond, Hizbullah ensured that the network of organisations affiliated with it served two functions: first, to mobilise resources towards the provision of social services to Lebanon's Shii population, and, second, to effect desirable social change by diffusing the moral rubrics and cultural symbols associated with the party's worldview. ${ }^{26}$ Despite Hizbullah's initial rejection of the consociational political system and its commitment to 'revolution,' it has participated in national and local elections since 1992 and has been represented in the government since 2005, but without surrendering its paramilitary wing or its willingness to use violence for political ends. ${ }^{27}$ Hizbullah has therefore consolidated its position as the dominant political actor, claiming as its prerogative the representation of the Shii

\footnotetext{
${ }^{25}$ For more on ideology, practices and early history of the party, see Saad-Ghorayeb, Amal (2002), Hizbu'llah: Politics and Religion (London: Pluto Press); Qassem, Naim (2005), Hizbullah: A Story from Within (London: Saqi); Mervin, Sabrina (2008), Hezbollah: État des lieux (Paris: Actes Sud); and Harb, Mona (2010), Le Hezbollah a Beyrouth: De la banlieue à la ville (Paris: Karthala)

${ }^{26}$ For more on Hizbullah's expansive network of social welfare organisations, see Harik, Judith Palmer (2004), Hezbollah: The Changing Face of Terrorism (New York: I.B. Tauris). On the relationship between Hizbullah's social welfare provision and Shii identity politics in Lebanon, see Cammett, Melani (2014a), Compassionate Communalism: Welfare and Sectarianism in Lebanon (Ithaca: Cornell University Press)

${ }^{27}$ Alagha, Joseph (2006), The Shifts in Hizbullah's Ideology: Religious Ideology, Political Ideology and Political Program (Amsterdam: Amsterdam University Press)

${ }^{28}$ May, Samantha (2019), "The Rise of the "Resistance Axis": Hezbollah and the Legacy of the Taif Agreement,' Nationalism and Ethnic Politics, 25 (1), pp. 115-132

${ }^{29}$ Sharara, Waddah (1998), Dawlat Hizballah: Lubnan

Mujtama' an Islamiyyan (The State of Hizbullah: Lebanon, an Islamic Society) (Beirut: Dar al-Nahar). Scholars of varying
}

community in Lebanon alongside the Amal Movement, the party's predecessor and competitor-turned-ally. Regionally, Hizbullah's importance is attributed to its armed struggle against Israel, its ties with the Iranian government, and its multifaceted entanglements in regional conflicts in Iraq, Syria, Yemen and the Gulf. ${ }^{28}$

Several sociological theories and political analyses are evoked in an attempt to make sense of Hizbullah's socalled "state within a state." 29 These explanations converge over the conviction that state weakness in Lebanon and the consequent 'power vacuum' are what allow Hizbullah to "behave with the responsibility of a sovereign" 30 and attain "state-like and non-state-like sovereign potentialities" (e.g. control over territory, welfare service provision, generation of markers of identity, and international recognition). ${ }^{31}$ Proponents of a stauncher anti-Hizbullah stance argue that the Shii movement is in fact "a state above the state," noting that Hizbullah members enjoy immunity from the judiciary and security agencies and that the party "has a free hand in bringing in goods and people through Lebanese ports, border crossings and the airport - no taxes paid, no questions asked." 32

With the global spread of neoliberalism in the 1990s, the question of state weakness gained new relevance. State theorists and political practitioners were forced to grapple with a new reality as the globalisation literature of the 1980s ushered in a narrative of wholesale state

political and disciplinary persuasions weighed in on the debate around Hizbullah's so-called "state within a state." See Early, Bryan R. (2006), 'Larger than a Party yet Smaller than a State: Locating Hezbollah's Place within Lebanon's State and Society,' World Affairs, 168 (3), pp. 115-128; AbdulHussain, Hussain (2009), 'Hezbollah: A State Within a State,' Current Trends in Islamist Ideology, 8, pp. 68-81; and Kindt, Michael T. (2009), 'Hezbollah: A State within a State,' in The World's Most Threatening Terrorist Networks and Criminal Gangs, ed. by Michael T. Kindt, Jerrold M. Post, and Barry R. Schneider (New York: Palgrave Macmillan)

${ }^{30}$ Atzili, Boaz (2010), 'State Weakness and "Vacuum of Power" in Lebanon,' Studies in Conflict E Terrorism, 33 (8), pp. 757-782

${ }^{31}$ Mansour, Imad (2017), 'The State of Hezbollah? Sovereignty as a Potentiality in Global South Contexts,' in The Oxford Encyclopedia of Empirical International Relations Theory, ed. by William R. Thompson (New York: Oxford University Press), Vol. 3, pp. 433-454.

${ }^{32}$ Nassar, Adib (2018), 'Hezbollah is a State Above the State,' The Arab Weekly (9 $9^{\text {th }}$ of September), p. 5 
'retreat' or 'eclipse' in an attempt to theorise the ideological project championed by Western leaders like Ronald Reagan and Margaret Thatcher. Theirs was an ideology premised on the belief that the State is "not the solution" to socioeconomic problems, but that "it is the problem," 33 and that "less state" and more freedom for markets and entrepreneurialism is in fact the solution. ${ }^{34}$

A corollary to this is the moral tenet that "it is our duty to look after ourselves and [each other]." As a result, it was assumed that states worldwide would 'shrink' and inevitably 'wither away' or be reduced to impotence. $^{35}$ For Lebanon, this meant that, as the country emerged from its civil war, the post-war order was expected to outsource state functions to non-state actors from civil society, the private sector, and sectarian organisations. This post-war political order was regionally brokered and internationally backed and approved, until the breakdown of the regionalinternational consensus that upheld it following the 2006 war with Israel and the regionwide popular uprisings of 2011.

An examination of whether the Lebanese State is 'weak' by historical design or has 'retreated' due to neoliberal globalisation is beyond the scope of this article. What concerns me here, however, is that these approaches share a certain theoretical conviction that the State is (or 'ought to be') an autonomous or semiautonomous entity (vis-à-vis an equally theoretical

\footnotetext{
${ }^{33}$ Reagan, Ronald (1981), 'President Ronald Reagan's Inaugural Address at the United States Capitol, 1/20/1981,' Records of the White House Communications Agency (WHCA). Available from the National Archives Catalogue (Identifier: 7087567), https://catalog.archives.gov/id/7087567 34 Thatcher, Margaret (1987), 'No Such Thing as "Society:" Interview with Douglas Keay,' Woman's Own (23rd of September). Available at: http://www.margaretthatcher.org/document/106689, pp. 30 ${ }^{35}$ For example, Jha, Praveen (2005). 'Withering Commitments and Weakening Progress: State and Education in the Era of Neoliberal Reforms,' Economic and Political Weekly, 40 (33), pp. 3677-3684; Radice, Hugo (2008), 'The Developmental State under Global Neoliberalism,' Third World Quarterly, 29 (6), pp. 1153-1174; Lobao, Linda, et. al. (2018), 'The Shrinking State? Understanding the Assault on the Public Sector,' Cambridge Journal of Regions, Economy and Society, 11 (3), pp. 389-408

${ }^{36}$ Brenner, Neil and Nik Theodore (2002), 'Cities and the Geographies of "Actually Existing Neoliberalism",' Antipode, 34 (3), pp. 349-379
}

construct: 'Society'). As a consequence, the state debate tended to reduce the State of Lebanon to a mere anomaly to the Weberian archetype or an aberration from grand theories of the state.

\subsection{The state 'as it really is': Mediated stateness and new state spaces}

This theoretical fixation has come under increasing scrutiny when confronted by contemporary debates on globalisation and the emergence of a post-Westphalian world order. Social research into variations and hybrid articulations of globalisation and 'actually existing neoliberalisms'36 resulted in increased awareness that neoliberal globalisation does not always result in the withering away of the State's control nor does it necessarily unleash the democratic potentials of free markets and civil societies. In particular, scholarship on the Arab world has shed light on the fine-tuned workings of political power, especially in the context of spaces and peoples living in what is allegedly "a state other than the [S]tate." This literature has demonstrated how Arab states, while increasingly absent from major economic and welfare sectors, maintain a tight web of control. ${ }^{37}$ This has allowed the States to consolidate prereform structures and relations masked by limited and reversible transformations. ${ }^{38}$ A feature of this has been the State's - newfound or revived - reliance on non-state actors. ${ }^{39}$ In Lebanon, this assumed a conspicuously

${ }^{37}$ Ismail, Salwa (2006), Political Life in Cairo's New Quarters: Encountering the Everyday State (Minneapolis: University of Minnesota Press)

${ }^{38}$ Beinin, Joel (2009), 'Neo-Liberal Structural Adjustment, Political Demobilization and Neo-Authoritarianism in Egypt, in The Arab State and Neo-Liberal Globalization: The Restructuring of State Power in the Middle East, ed. by Laura Guazzone and Daniela Pioppi (Reading: Ithaca), pp. 19-46. See also Hinnebusch, Raymond (2006), 'Authoritarian Persistence, Democratization Theory and the Middle East,' Democratization, 13 (3), pp. 373-395; and Heydemann, Steven (2007), 'Upgrading Authoritarianism in the Arab World,' Analysis Papers (Washington D.C.: Saban Center for Middle East Policy / Brookings Institution)

${ }^{39}$ Hinnebusch, Raymond (2000), 'Liberalization without Democratization in "Post-Populist" Authoritarian States,' in Citizenship and the State in the Middle East, ed. by Nils Butenschon, Uri Davis and Manuel Hassassian (New York, NY: Syracuse University Press), pp. 123-145; Bergh, Sylvia I. (2013), The Redeployment of State Power in the Southern Mediterranean: Implications of Neoliberal Reforms for Local Governance (New York, NY: Routledge), pp. 1-19; Bogaert, 
sectarian undertone ${ }^{40}$ enshrined by the Taif Agreement and reinforced by a network of partisan and religious institutions. ${ }^{41}$

The recognition that state and non-state actors are interdependent and mutually constitutive represented a major theoretical shift in scholarly engagements with the Lebanese state. Rather than dismissing the State as 'weak' or irrelevant, scholars of Lebanon show an increased aptitude for empirical inquiries that interrogate the boundaries and interplay between the State and its non-/ extra-state other(s), including the Sect as an amalgamation of religious and communitarian institutions. In other words, they question the boundaries between the State and its other(s), trace interdependencies between the two, and argue for 'hybrid sovereignties'. In so doing, they show that public authority is often "generated in the amalgamation of state and non-state institutions" which simultaneously "operate inside and beyond the Lebanese [S]tate"; thus, validating rather than challenging each other. ${ }^{42}$

I understand these conceptual propositions as examples of 'mediated stateness,' a notion introduced by Ken Menkhaus to account for the interdependence

Koenraad (2013), 'Contextualizing the Arab Revolts: The Politics behind Three Decades of Neoliberalism in the Arab World,' Middle East Critique, 22 (3), pp. 213-234

${ }^{40}$ Aggestam, Karen, et. al. (2009), 'The Arab State and Neoliberal Globalization,' in The Arab State and Neo-Liberal Globalization: The Restructuring of State Power in the Middle East, ed. by Laura Guazzone and Daniela Pioppi (Reading: Ithaca), pp. 325-236

${ }^{41}$ On the relationship between welfare provision, corruption and the establishment and consolidation of power in postwar Lebanon, see Leenders, Reinoud (2012), Spoils of Truce: Corruption and State-Building in Postwar Lebanon (Ithaca: Cornell University Press); and Cammett, Melani (2014b), 'Sectarian Politics and Social Welfare: Non-state Provision in Lebanon,' in The Politics of Non-State Welfare, ed. by Melani Cammett and Lauren M. MacLean (Ithaca: Cornell University Press).

42 Stel, Nora (2016), 'Languages of Stateness in South Lebanon's Palestinian Gatherings: The PLO's Popular Committees as Twilight Institutions,' Development and Change, 47 (3), pp. 449; Stel, Nora (2020), Hybrid Political Order and the Politics of Uncertainty: Refugee Governance in Lebanon (New York, NY: Routledge); also Fregonese, Sara (2012), 'Beyond the "Weak State:" Hybrid Sovereignties in Beirut,' Environment and Planning, 30, pp. 655-674; Hourani, Najib (2013), 'Lebanon: Hybrid Sovereignties and U.S. Foreign Policy,' Middle East Policy, 20 (1), pp. 39-55; and Hazbun, Waleed (2016), 'Assembling Security in a "Weak State:" The between the State and the "rival sources of authority to provide core functions of [government]." 43 According to Menkhaus, the State can rely on a diverse range of nonstate actors to execute core functions of government and mediate relations with local communities. ${ }^{44}$ Empirical research from a variety of contexts recognises this as a useful approach that captures the uneasy collaboration between non-state actors with authority not contingent on the State and the states with which they co-exist. This has demonstrated that the adversarial relationship which theorists and practitioners expected between the State and its other(s) is often replaced by forms of accommodation and pragmatic compromise. ${ }^{45}$ Such analyses also showed how mediated stateness takes on various institutional and relational forms, including 'twilight institutions' 46 and polycentric and multilevel governance. ${ }^{47}$

To unpack the fine-tuned workings of mediated stateness, I adopt a "geographically attuned and scalesensitive approach to state theory," inspired by Neil Brenner's inquiry into the 'new state spaces' that are being produced under contemporary processes of late capitalism and state rescaling. ${ }^{48}$ I propose that this approach has two important implications: Firstly, it

Contentious Politics of Plural Governance in Lebanon Since 2005,' Third World Quarterly, 37 (6), pp. 1053-1070

${ }^{43}$ Menkhaus, Ken (2006), 'Governance without Government in Somalia: Spoilers, State Building, and the Politics of Coping,' International Security, 41 (3), pp. 78

${ }^{44}$ Ibid, pp. 103

${ }^{45}$ Kasfir, Nelson, Georg Frerks and Niels Terpstra (2017), 'Introduction: Armed Groups and Multi-Layered

Governance,' Civil Wars, 19 (3), pp. 264

${ }^{46}$ Christian Lund coined the term to describe institutions that "have a twilight character": they are not the state but possess an authority and ability to define and enforce collectively binding decisions. Lund's metaphor signifies that the contours and features of these institutions are hard to distinguish and discern. See Lund, Christian (2006), 'Twilight Institutions: An Introduction,' Development and Change, 37 (4), pp. 673

${ }^{47}$ Elisabeth Nauclér defines multilevel governance as "the distribution of power and competences through the vertical layering of public authority from the supra-state to local government level." See Nauclér, Elisabeth (2005), 'Autonomy and Multilevel Governance: Experiences in Nordic and Continental European Cooperation,' in Autonomy, SelfGovernance and Conflict Resolution: Innovative Approaches to Institutional Design in Divided Societies,' ed. by Marc Weller and Steffan Wolff (New York, NY: Routledge), pp. 85 ${ }^{48}$ Brenner, Neil. 2004. New State Spaces: Urban Governance and the Rescaling of Statehood (New York: Oxford University Press), pp. 2 
"unsettles the state-centric geographical categories and scalar assumptions that have long underpinned traditional, disciplinary approaches to social science, in which social, economic, and political processes are presumed to be geographically congruent within national-state boundaries." 49 Secondly, the concept of state spaces lends itself to a more synthetic, multiperspectival understanding of space inspired by the seminal contributions of radical urbanists. ${ }^{50}$ According to their socio-spatial dialectic, the traditional notion of 'space-as-thing' is substituted with a socialconstructionist notion of 'space-as-process;' the idea at the heart of Henri Lefebvre's 'production of space'. Applied to state analysis, this processual approach promises to reveal the social relations constituting the State; thus, contributing to an extended and socially embedded understanding of the State.

In what follows, I pursue an analysis of the State in Lebanon, informed by an empirical inquiry into the finetuned workings of mediated stateness in Beirut's southern suburbs. I propose that the management of post-war reconstruction in Dahiya following Israel's war on Lebanon in 2006 is an illustrative example of regimes of governance and rule which diverge from the Weberian-Westphalian prescriptions of the modern State. I argue that these regimes of rule should not be dismissed as instances of state weakness or failure, nor should they be understood as "heterarchic zones of limited statehood"51 where state sovereignty is undermined by sub-/supranational actors. Rather, I conceptualise these regimes as the outcome of the systemic re-organisation of the State. Furthermore, I demonstrate that these new state spaces are produced through the interaction between the myriad actors involved in governing 52 Dahiya.

\footnotetext{
${ }^{49}$ Ibid, pp. 23

${ }^{50}$ Harvey, David (1973), Social Justice and the City (Baltimore, MD: Johns Hopkins University Press); Castells, Manuel (1977 [1972]), The Urban Question: A Marxist Approach (Cambridge: MIT Press); Soja, Edward W. (1980), 'The socio-spatial dialectic,' Annals of the Association of American Geographers, 70, pp. 207-255; and Lefebvre, Henri (1991 [1974]), The Production of Space (Cambridge: Blackwell)

${ }^{51}$ Hinnebusch, Raymond (2018), 'From Westphalian Failure to Heterarchic Governance in MENA: The Case of Syria,' Small Wars and Insurgencies, 29 (3), pp. 391-413

52 I understand governance as a political (rather than a technocratic) endeavour, which entails "the formation and stewardship of the formal and informal rules that regulate the public realm." See: Hydén, Göran, Julius Court, and Kenneth
}

\section{OPERATION SOLEMN PROMISE: HIZBULLAH AND THE TRANSFORMATION OF DAHIYA}

In Lebanon, Beirut's southern suburbs are often described as a stronghold of the non-state Shii political movement and armed resistance group, Hizbullah. The suburbs are cited as a poignant example of a 'threatening' or 'problematic' geography. Lumped together into a single political territory, known locally by the common parlance, Dahiya (literally, "the suburb"), they conjure a sense of peripherality and imaginaries of an ungovernable Shii ghetto. For almost three decades, Hizbullah has been successful at affirming its position as the dominant political force in Dahiya, overriding its archenemy-turned-ally, the Amal Movement. More recently, Dahiya witnessed a significant socio-urban transformation since 2006, shaped by Hizbullah's two promises: the promise to secure the release of Lebanese detainees in Israeli prisons and establish deterrence vis-à-vis Lebanon's southern neighbour; and the promise to rebuild Dahiya. ${ }^{53}$

In fulfilling its first promise, Hizbullah fighters carried out a cross-border operation on July 12, 2006, killing eight Israeli soldiers and kidnapping two. Dubbed Operation Solemn Promise (al-wa'ad al-șādiq), the skirmish unleashed Israeli's wrathful response. Guided by the so-called Dahiya Doctrine, an Israeli military strategy of asymmetric warfare, the Israeli military believed that, by increasing the humanitarian cost of war and the cost of post-war recovery, the Jewish State could achieve deterrence vis-à-vis its non-state rivals and avoid a protracted war of attrition. ${ }^{54}$ Israel wrecked Lebanon's civilian infrastructure, causing as much human and material devastation as possible. Dahiya bore the brunt of the wrathful aerial

Mease (2004), Making Sense of Governance: Empirical Evidence from Sixteen Developing Countries (Boulder: Lynne Rienner), pp. 16

${ }^{53}$ Nasrallah made his famous pledge that "we are a people who do not leave our prisoners [of war] behind." The pledge was part of his speech during a meeting of Hizbullah's Women's Organizations Unit on the 31 ${ }^{\text {st }}$ of March 2001. See Shidyaq, Imad (2007), al-Muqāwamah wa-sayyiduhā Hasan Naṣr Allāh (The Resistance and its Master: Hassan Nasrallah)

(Beirut: al-Maktaba al-Hadītha), pp. 102

${ }^{54}$ Marei, Fouad Gehad (2020), 'Dahiya Doctrine', in Conflict in the Modern Middle East: An Encyclopaedia of Civil War, Revolutions and Regime Change, ed. by Jonathan K. Zartman (Santa Barbara: ABC-CLIO) 
bombardment. Initial surveys listed 1,332 severely damaged multi-storey buildings of which 281 were completely raised to the ground and some 100,000 civilians displaced. ${ }^{5}$

Mindful of the magnitude of the carnage and the strategic objective behind Israel's disproportionate response, Hizbullah Secretary-General, Hassan Nasrallah, pledged to restore Dahiya "more beautiful than it was [...] and for all its residents." 56 Befittingly, the televised victory speech was broadcast over the wreckage that had become of Haret Hreik, the social and commercial heart of Dahiya. The speech demonstrated Hizbullah's conviction that "victory is only complete when we rebuild these houses so that the honourable [people], without whose resilience and support this Resistance would not be, can return to their homes and lives." 57

To achieve that, Hizbullah mobilised its financial and noncombat resources and rallied its foreign and domestic web of relations, kick-starting its largest reconstruction effort to date. The project was guided by a laser-beam focus on the rapid alleviation of civilian suffering and on-site resettlement of the displaced, "as quickly and as comprehensively as possible." 58 The project was born in a highly polarised political environment as the war failed to bring the Lebanese belligerents closer. Instead, Lebanon entered a protracted political stalemate, characterised by Hizbullah's boycotting of the government. Amidst this tumultuous political environment, Waad Rebuild (hereafter, Waad), the agency established by Hizbullah to oversee post-war reconstruction, was officially launched in a press conference held in the Municipality of Haret Hreik in May 2007. It was envisaged that the agency would operate outside national state institutions, $^{59}$ a decision which reflected a public

\footnotetext{
${ }^{55}$ Fawaz, Mona (2014), 'The Politics of Property in Planning: Hezbollah's Reconstruction of Haret Hreik (Beirut, Lebanon) as a Case Study,' International Journal of Urban and Regional Research, 38 (3), pp. 922-934

${ }^{56}$ Nasrallah made this pledge in his victory speeches on the 14 $4^{\text {th }}$ of August 2006 and the 22nd of September 2006 (Victory Rally). Nasrallah reiterated this pledge on the $12^{\text {th }}$ of November 2006, at the peak of the governmental crisis and in the aftermath of the resignation of all six Shii ministers. Transcripts of speeches by Hizbullah chief are published in several Lebanese newspapers and online on almanar.com.lb and moqawama.org. For transcripts (in Arabic), see Shidyaq (2007), ibid; and (in English) Noe, Nicholas (ed.) (2007), Voice of Hezbollah: The Statements of Sayyed Hassan Nasrallah (New York: Verso)
}

opinion unfavourable of government-led urban interventions. This was also in line with the Lebanese government's neoliberal commitments, which limited the role of the State to the provision of immediate relief and the facilitation of private sector-led reconstruction. ${ }^{60}$

Hizbullah's post-2006 reconstruction effort was thus conceived independent of the state's labyrinthine bureaucracy and, it was hoped, immune to its clientelistic mechanisms. ${ }^{61}$ Waad provided an organisational superstructure that ensured synergistic partnership between private-sector real estate developers, Hizbullah-run municipalities, faith-based organisations and elite factions of civil society, and foreign state and non-state donors. To enable the project, Hizbullah asked residents of war-affected neighbourhoods to sign off their state compensations to Waad. This granted the agency the authority to collect relief payments earmarked by the Lebanese government in addition to donations mobilised by Hizbullah. Alternatively, residents were offered financial imbursements by the government to assist them in rebuilding damaged and destroyed properties. For most, the latter was unfavourable: Firstly, many feared that state compensation would not suffice or that it would get caught up in endless political quagmires and bureaucratic hurdles. Secondly, dense multi-storey housing in Dahiya rendered rebuilding individual properties implausible.

\subsection{The contentious politics of an urban intervention}

In his victory speech, Nasrallah outlined his party's vision for post-war reconstruction: "we will restore it more beautiful than it was" (sanu'ìduha ajmal mi(n)-mā

${ }^{57}$ Speech on the $14^{\text {th }}$ August 2006. See Shidyaq (2007), ibid, pp. 324.

${ }^{58}$ Hassan Jeshi, Managing Director of Waad for Reconstruction. Author's interview (Beirut: $3^{\text {rd }}$ March 2010)

${ }^{59}$ Harb, Mona, and Mona Fawaz (2010), 'Influencing the Politics of Reconstruction in Haret Hreik,' in Lessons in PostWar Reconstruction: Case Studies from Lebanon in the Aftermath of the 2006 War, ed. by Howayda Al-Harithy (New York: Routledge), pp. 21-45

${ }^{60}$ Hamieh, Christine S. and Roger MacGinty (2011), 'Reconstructing Post-2006 Lebanon: A Distorted Market,' in Rethinking the Liberal Peace: External Models and Local Alternatives, ed. by Shahrbanou Tadjbakhsh (New York: Routledge), pp. 181-94

${ }^{61}$ Marei (2016), pp. 175 
kānat) and "for all its residents." 62 The seemingly oxymoronic statement highlights the political agendas at play. Hizbullah promised to restore social life, while also effecting desirable change and improving the quality of life in Dahiya, without altering its demography. Guided by this vision, Waad was conceived as "more than just a restoration of the built environment." 63 This reflected a conviction amongst Hizbullah activists and politicians that Dahiya is 'disorderly,' a condition which they only partly attribute to state negligence and structural imbalances.

According to Mohammad Said Al-Khansa, Hizbullah's strongman in Dahiya and Mayor of Ghobeiri, "residents of Dahiya are to blame." According to the pro-business mayor, there is a "sense of impunity and disorderliness which [residents of Dahiya] have internalised ... This is a problem that plagues Dahiya and discourages investment." 64 As his statement indicates, the impetus to address perceived disorderliness stems from a strategic need to create socioeconomic opportunities befitting the Shii community's acute socioeconomic leap while also reflecting the regional rise of Hizbullah's military and political prowess. In other words, Hizbullah officials saw post-war reconstruction as "a unique opportunity to address deeper problems in Dahiya and improve life ... not only in the areas directly affected by the war ... [It] was an opportunity to make Dahiya 'better than it was,' as Sayyid [Hassan Nasrallah] promised." 65

\footnotetext{
62 Speeches on the $14^{\text {th }}$ of August and 12th of November 2006. Nasrallah's statement is often translated as "we will rebuild it better more beautiful than it was." While this does capture the intention of the statement, I would like to emphasise Nasrallah's original choice of words, "we will return it (sanu'iduha) more beautiful than it was," indicating an intention to restore and improve Dahiya. Moreover, Nasrallah used the word afdal (improved) in his speech on the $14^{\text {th }}$ of August, and ajmal (more beautiful) in the speech on the $12^{\text {th }}$ of November

63 Jeshi, ibid

${ }^{64}$ Mohammad Said Al-Khansa, Mayor of Ghobeiri. Author's interview (Beirut: 30th September 2014)

${ }^{65}$ Hussein Fadlallah, Al-Nizam min Al-Iman Campaign Coordinator. Author's interview (Beirut: 15 ${ }^{\text {th }}$ April 2010). See Marei, Fouad Gehad (2016), 'Preaching Development: Shi'i Piety and Neoliberalism in Beirut', in Religious Activism in the Global Economy, ed. by Sabine Dreher and Peter J. Smith (Washington D.C.: Rowan and Littlefield), pp. 167-187. ${ }^{66}$ Al-Harithy, Howayda (ed.) (2010), Lessons in Post-War Reconstruction: Case Studies from Lebanon in the Aftermath of the 2006 War. (New York: Routledge); Fawaz, Mona (2014), 'The
}

Waad was therefore designed as an institutional space where a reorganised Dahiya was imagined, planned and operationalised. ${ }^{66}$ High-ranking officials affiliated with Hizbullah's reconstruction arm, Jihad alBina, recruited a coterie of Lebanese architects and planners for the Consultative Committee commissioned to guide the reconstruction project. Two Hizbullah officials were instrumental: Hassan Hijazi, an affluent real estate developer affiliated with Jihad al-Bina and the head of the Independent Professions in Hizbullah's Syndicate Unit, ${ }^{67}$ and Sultan Asaad, the head of the party's Central Unit for Municipal Action. ${ }^{68}$ The two Hizbullah officials nominated seventy-year-old excommunist activist and President of the Organisation of Arab Architects, Rahif Fayad, to preside over the sixmember Committee. Under his chairmanship, the Committee embarked on developing a master plan, a process which shed light on the diverging visions for post-war Dahiya: What should a restored-andimproved Dahiya look like? Which models and processes of reconstruction should Hizbullah's Capital of the Resistance employ?

Fayad, who was branded by leftists and Hizbullah supporters as "architect of the Resistance," saw this as

Politics of Property in Planning: Hizbullah's Reconstruction of Haret Hreik (Beirut) as Case Study', International Journal of Urban and Regional Research, 38 (3), pp. 922-934.

67 The Syndicate Unit was established in 1996 and is subordinate to Hizbullah's Executive Council. It is responsible for guiding Hizbullah representatives in syndicates, professional associations and student unions. See Hamzeh, Ahmad Nizar (2004), In the Path of Hizbullah (New York: Syracuse University Press), pp. 61.

${ }^{68}$ The Central Unit for Municipal Action is subordinate to Hizbullah's Executive Council. It is responsible for coordinating Hizbullah representatives in local government. Sultan Asaad is also a close aide of Sayyid Hashim Safieldine, the head of the Executive Council and Nasrallah's cousin, lookalike and heir apparent. On the 17th of September 2020, the U.S. Department of Treasury's Office of Foreign Assets Control (OFAC) designated Sultan Asaad as a Specially Designated National (SDN), sanctioning him on grounds of being "responsible for dozens of companies subordinate to" Hizbullah and which "permeate all aspects of the Lebanese economy, including the construction and infrastructure sectors." See: https:/ / home.treasury.gov/news/pressreleases/sm1126 
an opportunity to put into effect his staunch opposition to neoliberal urban development and 'starchitecture:' 69

'Reconstruction should resist the estranging tendencies of the real estate development sector in the Arab world ... We don't need a construction industry that empties the soul and identity of the city and deprives society of its humanity, history and memory ... We don't need an architecture that is driven by art or business or luxury ... We need an architecture that is like anthropology: focused on the social and not on the technical production of buildings and skyscrapers that rise above one another ... We need to resist starchitectures of publicity and globalisation. We don't want to 'brand' Beirut the way Dubai or Abu Dhabi are branded'.70

While benefitting from the neoliberal retreat of the State from urban development and reconstruction, this ideological position gave Waad an intellectual justification, branding it as a form of resistance not only to Israel but also to the precepts of neoliberal globalisation and urbanity. It is in this light that Fayad insisted on "preserving the "memory of place" (al-hifäz 'alā zākirat al-makān). Citing the post-war reconstruction of Downtown Beirut by former Prime Minister, Rafik Hariri, 71 Fayad warned that developers will "displace the people," erase their 'memory of place,' and treat Dahiya as a tabula rasa for the creation of rent through profit-driven real estate developments. ${ }^{72}$ For Fayad,

\footnotetext{
${ }^{69}$ Starchitecture is a portmanteau used to describe architectural products which derive fame and celebrity from style and aesthetic, and which are systematically used as means and icons for urban branding. Starchitecture is often contrasted to an architecture that promises urban success and social value. See Ponzini, Davide, and Michele Nastasi (2017), Starchitecture: Scenes, Actors, and Spectacles in Contemporary Cities (New York: Monacelli Press).

${ }^{70}$ Rahif Fayad, Former president of the Organisation of Arab Architects and chairman of Waad's Consultative Committee. Author's interview (Beirut: 15th December 2015)

${ }^{71}$ On the political economy of post-civil war reconstruction in Lebanon, see, for example, Verdeil, Éric (2001),

'Reconstructions Manquées à Beyrouth: La poursuite de la guerre par le project urbain,' Annales de la recherché urbaineVilles et guerres, 91, pp. 65-73; Schmid, Heiko (2002) 'The Reconstruction of Downtown Beirut in the Context of Political Geography,' The Arab World Geographer, 5 (4), pp. 232-248; and Baumann, Hannes (2017), Citizen Hariri: Lebanon's Neoliberal Reconstruction (New York: Oxford University Press). On the changing modalities of governing and organising the built environment in Beirut and its
}

modelling Beirut "after Gulf cities in the post-war moment was less a vision for the future, as Hariri and his corporation advocated, than a violation of the past." 73 He therefore demonstrated great aversion for the introduction of any significant changes to the built environment.

Other architects and urban planners opposed Fayad's ultraconservative approach, arguing that post-war reconstruction should be treated as an opportunity to rectify rampant building and zoning irregularities and improve housing quality in Dahiya. They advocated for more ambitious developments driven to improve the quality of social life in Dahiya. One of these critics was Mona Fawaz who was also approached by Hassan Hijazi in 2006, only to be excluded from consultations with Waad a few months later.

Fawaz is professor of urban studies and planning at the American University of Beirut and a political and urban activist critical of urban policy in Beirut and its suburbs. Commenting on Rahif Fayad's 'memory of place' thesis, she exclaimed: "I repeatedly asked him: can't you restore buildings 'more beautiful than they were'?! Is facing the mouldy toilets and crumbling plumbing of one's neighbour also part of 'the memory of place' that you want to preserve?!"74 Fawaz has argued elsewhere that the Hizbullah-run reconstruction project was informed by a "consolidated, abstracted definition of space" defined by the interest of "capital be it economic or political,"75 and that it reinforces the division between Dahiya and the rest of the city. ${ }^{76}$

environs, see Krinjnen, Marieke, and Mona Fawaz (2010), 'Exception as the Rule: High-End Developments in Neoliberal Beirut,' Built Environment, 36 (2), pp. 245-259

${ }^{72}$ Rahif Fayad developed his critique of neoliberal urbanism and starchitecture in a series of newspaper articles and university lectures, which were collated and republished in his book. See Fayad, Rahif (2010), Min al-'Imāra ilā al-Madīna (From Architecture to Urbanism) (Beirut: Dar Al-Farabi)

${ }^{73}$ Monroe, Kristin V. (2016), The Insecure City: State, Power and Mobility in Beirut (New Brunswick: Rutgers University Press), pp. 51

${ }^{74}$ Mona Fawaz, Professor of Urban Studies and Planning at the American University of Beirut, and political activist and co-founder of Beirut Madinati. Author's interview (Beirut: $13^{\text {th }}$ November 2015).

${ }^{75}$ Ghandour, Marwan, and Mona Fawaz (2010), 'Spatial Erasure: Reconstruction Projects in Beirut,' ArteEast Quarterly. Available at: http://arteeast.org/2012/02/05/spatialerasurereconstruction-projects-in-beirut.

${ }^{76}$ Fawaz, Mona (2009), 'Hezbollah as Urban Planner? Questions to and from Planning Theory,' Planning Theory, 8 (4), pp. 323-334. 
Other members of the Consultative Committee, including Hana Alamuddin, CEO and Principal Architect of of Al-Mimariya Architects and Designers and Lecturer at the American University of Beirut, and Mahmoud Charafeddine, CEO of Architectural Team for Construction and Professor at the Lebanese University, echoed similar concerns. Alamuddin and Charafeddine shared the opinion that the social fabric in Dahiya must be restored and that reconstruction should not be subordinated to the profit-driven logics of global capital. However, they did not share the same inaptitude with which Fayad approached proposals for improvement and change. More controversial criticism emerged from Sany Jamal, another member of the Committee, who accused Waad of "bulldozing the social, economic, cultural and relational commitments between people and space in favour of a town and a society designed elsewhere in the name of 'the Resistance'."77

A comprehensive and conclusive discussion of the different opinions and visions for post-war reconstruction in Dahiya is beyond the scope of this article. However, a quick presentation of some of the negotiations that took place within the Consultative Committee suffices to show that the nongovernmental agency served as the locus of policy discussions and a new state space where different processual visions for the practice and outcome of post-war reconstruction were articulated and negotiated. Essentially, Waad sought to reconcile these diverging visions, aligning them with the political and strategic concerns of Hizbullah. Moreover, the agency and its subcommittees mediated the relationship between the various stakeholders in reconstruction and accommodated their different interests. Consequently, its directors sought to ensure the feasibility and profitability of the construction contracts awarded and reduce the likelihood that disputes would arise between contractors and homeowners. The agency also positioned itself as the only go-between in disputes between residents, contractors and government authorities:

\footnotetext{
77 Sany Jamal, CEO of Jamal Architects and Engineers and a member of Waad's Consultative Committee. Author's interview (Beirut: 28 $8^{\text {th }}$ December 2015).

${ }^{78}$ Mounir Makki, Director of Waad's Liaison Office for Residents' Affairs. Author's interview (Beirut: $28^{\text {th }}$ November 2015)
}

'Residents were instructed to communicate with [construction contractors] through [Waad's] Liaison Office for Residents' Affairs ... They could direct any complaint to us and we negotiated with the construction companies on their behalf. We also provided homeowners and residents with legal and bureaucratic support, especially to claim government compensation or settle disputes with the authorities. This was important for residents of buildings which violated zoning and building regulations or had outstanding municipal debts' ${ }^{78}$

Acting as the sole channel of communication between residents, the government and construction contractors, Waad reiterated its commitment to Hizbullah's laserbeam focus on the alleviation of the humanitarian cost of the war, a goal the Shii political party identified as precondition for its proclamation of victory against Israel.

In pursuit of this delicate balance, the agency adopted a master plan erring on the side of minimal change; thus, leveraging restoration over improvement. This inevitably meant limiting the scale of the project to the severely ravaged neighbourhoods and reducing its scope to physical reconstruction. ${ }^{79}$ Only minimal changes were introduced to external design, quality upgrades in building materials, enhanced seismic design (and thus increased resistance to future Israeli air strikes), and the implementation of uniform building finishes on the scale of multiple buildings. ${ }^{80}$

This significant compromise reflected Hizbullah's residents-first attitude, an attitude driven less by a concern for the wellbeing of the community than by the party's political fears and anxieties. Essentially, Fayad's aversion to neoliberal urbanity and starchitecture resonated with Hizbullah's fear that "any delay in the return of the displaced to their homes and lives is a victory to Israel." ${ }^{81}$ In other words, it was the legitimacy and popularity of the Shii political party that were at stake: delays in implementation or disputes with aggrieved residents risked eroding Hizbullah's reputation as a capable powerbroker and threatened to draw a wedge between the party and its social support

\footnotetext{
${ }^{79}$ Fawaz (2009), ibid

${ }^{80}$ Jeshi, ibid

${ }^{81}$ Jeshi, ibid
} 
base. By contrast, successful implementation and residents' swift return to their homes "generated the opportunity for Hizbullah to delineate [Dahiya] as its territorial base in [Beirut], thereby consolidating its claim for power with facts on the ground" and allowed the party to "define who will use the neighbourhood and which practices will be possible." 82 In this political environment, Waad was able to give Dahiya only a limited 'upgrade' and a superficial aura of orderliness, rather than bring about meaningful change to the quality of social life.

\subsection{Glocalising Dahiya: The global reach of local government}

With the improve aspect of Nasrallah's promise to "restore Dahiya more beautiful than before" compromised at the level of privately-owned residential buildings, it became imperative for the urban intervention to bring about changes to public and semipublic spaces. This entailed a shift from an emphasis on damaged and destroyed private homes to municipal and public properties: creating parking lots, removing or regularising transgressions on sidewalks and public spaces, re-regulating traffic, and the beautification of parks and municipal gardens. However, such improvements were not within the legal jurisdiction of Waad. To circumvent this jurisdictional limitation and allow the agency to effect desirable change at the level of the city, Waad engaged local authorities in quasigovernmental institutional set-ups. This resulted in the consolidation of a new urban coalition. ${ }^{83}$ With the agency constituting the locus of this coalition, the state's

\footnotetext{
${ }^{82}$ Fawaz (2009), ibid, pp. 331

${ }^{83}$ Martin Meyerson proposes the concept of 'new urban coalition' to describe the emergence of working alliances effecting urban policy, ostensibly for the not-so-well-off while, in fact, benefitting the well-off. See Meyerson, Martin (1968), 'Urban Policy: Reforming Reform,' Daedalus, 97 (4), pp. $1410-1430$

${ }^{84}$ Marei (2016), ibid

${ }^{85}$ Ahmad Hatoun, Deputy Mayor of Haret Hreik. Author's interview (Beirut: 30th September 2014)

${ }^{86}$ According to the Lebanese Municipal Act, a union of municipalities is charged with pooling the resources and coordinating the executive prerogatives of its member municipalities to deliver public services and strategic planning affecting two or more of its members. Moreover, unions of municipalities can negotiate with the central government regarding national projects and infrastructures
}

(neoliberal) role as a proactive enabler client of non/extra-state actors was reinforced. ${ }^{84}$

According to the Deputy Mayor of Haret Hreik, Ahmad Hatoum, a staunch ally of Waad and its main enabler in the hard-hit neighbourhood, "the role of the municipality was to provide Waad with the legal and regulatory tools necessary to implement and enforce changes to public spaces and municipal properties and to integrate its vision of the city into long-term policymaking at the local level." 85 The Union of Dahiya Municipalities, which represents local government at the meso or regional level, played a similar role in enabling Waad to influence changes that were Dahiyawide in scale and urban in scope. ${ }^{86}$

In other words, the quasigovernmental institutional framework involving Waad and its local government enablers placed at the disposal of the nongovernmental reconstruction agency important policymaking resources. In addition, it allowed the urban rehabilitation endeavour to capitalise on the law enforcement agencies at the disposal of the Union and its four member municipalities. In particular, municipal police and civil defence forces utilised their broad executive powers to assist and ensure the implementation and proper exercise of municipal regulations enacted in the context of the project. ${ }^{87}$ In the case of Dahiya, municipalities acted as the backbone of a new state space, which generated an opportunity for Hizbullah to redeploy its partisan organisations and social institutions under the municipal umbrella. For example, the Islamic Health Organisation constitutes the backbone of the Union of Dahiya Municipalities' Healthcare and Rapid Response Unit.88 This redeployment of Hizbullah's health organisation

within the jurisdiction of its member municipalities. Among the important national infrastructures within the jurisdiction of Dahiya municipalities is the Beirut Rafic Hariri International Airport and the Airport Road connecting it to the city. Dahiya is also home to the controversial Costa Brava landfill, which was opened in April 2016 by the Lebanese government as a temporary solution to the eight-month 'waste crisis' of 2015. See Marei, Fouad Gehad (2019), Are Municipalities in Lebanon Delivering? Survey Results on Solid Waste Management, Public Safety and Government Transparency (Berlin: Democracy Reporting International).

${ }^{87}$ Marei (2019), ibid

${ }^{88}$ Founded in the second-half of the 1980s, the Islamic Health Organisation is subordinate to Hizbullah's Executive Council. The organisation provides public health services in Shiimajority regions in Lebanon, constituting the backbone of a network of private and charitable Islamic hospitals. 
allowed it to access state resources and empowered it with broad governmentally sanctioned executive powers. A similar redeployment of Hizbullah's controversial Indibat torce under the umbrella of the municipal police force is widely observable though not openly discussed. Previously, the Indibāt, whose name literally means 'discipline,' acted as an extra-legal police force, answering only to the party's Executive Council. In short, municipalities in Dahiya act as the coalescing backbone of new state spaces and models of governance which integrate elite factions of civil society associated with Hizbullah and the junior clerics that constitute the Shii political milieu in Lebanon.

What is more, Hizbullah-run municipalities present the Shii political party and its non-/extra-state agencies with another indispensable resource: the (arguably only) legitimate and internationally recognised framework and main mediation structure with foreign governmental and sub-/supra-governmental actors. This is evidenced by the experience of the Union of Dahiya Municipalities, as described by its president:

'The Union works closely with Waad, with civil society organisations, with political parties in Dahiya, with Hizbullah associations, and with the private sector to identify needs, brainstorm ideas, and initiate developmental project ... Wherever our priorities converge with donor organisations' funding priorities, we engage them on the basis of equal partnership: we plan together and we co-finance projects on a dollar-todollar basis ... In Dahiya, we don't subordinate policymaking to the whims of the donor' ${ }^{\prime}{ }^{89}$

Mohammad Dorgham, who also served as a board member for the Lebanon Bureau of the Kuwait Fund for Arab Economic Development, insists that Dahiya municipalities act as "partners not recipients" of development assistance. While he attributes this to "the political awareness of the [Islamic] Resistance," this modality of collaboration conjures a vocabulary similar to that of international development cooperation practitioners. In the case of Dahiya, this became particularly evident as intergovernmental organisations

\footnotetext{
${ }^{89}$ Dorgham, ibid.

90 This is outlined in the ART GOLD Project Document. The document was signed in 2006 by UNDP Lebanon and the Council for Development and Reconstruction (CDR) on behalf of the Lebanese government. The ART GOLD Lebanon Programme commenced in March 2007. As a matter of
}

offered assistance in the aftermath of the 2006 war. For example, the United Nations Development Programme (UNDP) kick-started the Lebanon leg of its ART GOLD Global Initiative, the main arm of its support to local development. The initiative foregrounds two interrelated principles of global development assistance. Firstly, it fosters cooperation between sub-state actors and local governments rather than inter-governmental cooperation. Secondly, it promotes the humanitariandevelopment-peace nexus, positing that peacebuilding, humanitarian assistance, and crisis response plans in countries affected by conflict or natural disasters must be intercoupled with medium- and long-term sustainable development. ${ }^{90}$ According to the Responsible Officer for ART GOLD Beirut Southern Suburbs, Marie-Helène Kassardjian, 'partnership' as a mode of engagement between local authorities and aid providers was a new concept to Lebanon:

'Municipalities were accustomed to receiving development assistance either to finance projects addressing local needs or to apply ad-hoc interventions proposed by donor agencies. ART GOLD proposed a multilateral approach, leveraging decentralised cooperation and participatory project planning ... It did not arrive in Lebanon to finance or support specific projects, but to establish a working process. We supported the establishment of platforms for long-term partnership between donors and local authorities as well as the private and public sectors ... We want[ed] to replace the idea that the public sector receives development assistance and then contracts private companies to provide paid services' ${ }^{91}$

The UNDP's programmatic intervention assisted municipalities in Dahiya to act as the locus of multistakeholder forums involving local governments, donors, and the private sector "as partners." Kassardjian noted that, for ART GOLD, "municipalities were the natural and most effective entry point to Dahiya," as they "represent the [executive] authority at the local and regional levels, while also avoiding the political

protocol, the Project Document was ratified annually. The author obtained a copy of the document ratified in March 2013 from an informant.

${ }^{91}$ Marie-Helène Kassardjian, Responsible Officer for ART GOLD Beirut Southern Suburbs, UNDP. Author's interview (Beirut: 13 ${ }^{\text {th }}$ April 2016) 
obstacles of national politics." 92 However, she also reiterated that the initiative was made possible only because of concessions made by the central government, represented by the Council for Development and Reconstruction (CDR). ${ }^{93}$ Essentially, this government sanctioned scheme fostered international cooperation between local and regional authorities and the private sector, bypassing the central government.

An important consequence of strategically positioning Dahiya within the supranational economies and institutional make-up of decentralised development cooperation actors has been the crystallisation of farreaching partnerships between its municipalities and their counterparts in the global North. Already within the timeframe of the ART GOLD Beirut Southern Suburbs programme, Dahiya entered into multilateral inter-municipal cooperation schemes with local and regional governments in Lazio, Tuscany, Monaco, Catalonia, and Barcelona. Another consequence has been the strengthening of relations between Dahiya and foreign governmental development cooperation agencies. These included not only agencies from affluent countries of the global North, but also international development assistance agencies in the oil-rich Gulf monarchies. Most notably, these included the Kuwait Fund, which financed several projects in Dahiya, including the rehabilitation of state schools, building municipal sports centres and public libraries, and the construction of a new headquarters for the Union of Dahiya Municipalities and its police and civil defence forces.

In short, as Hizbullah limited the scale and scope of its post-war reconstruction effort and as the project neared completion, the Union of Dahiya Municipalities and its four member municipalities emerged as the new locus of power and the core of the rescaled and (onceagain) reconfigured model of governance in Dahiya. Coalescing a broad array of stakeholders and blurring the fuzzy boundaries between the different scales and categorical imperatives at which they operate, Hizbullah-run municipalities became the backbone of the new state spaces that govern Dahiya.

\footnotetext{
92 Kassardjian, ibid

${ }^{93}$ CDR was established in 1977 and reinstated in 1990. It is responsible for designing and supervising post-war reconstruction in the aftermath of Lebanon's civil war. CDR enjoys wide powers, often superior to those of the cabinet. It
}

\section{NEW STATE SPACES AND MEDIATED STATENESS IN BEIRUT'S SOUTHERN SUBURBS}

In this article, I empirically examined the regimes of governance and rule that emerged in Beirut's southern suburbs after the 2006 war with Israel. I considered some of the political and institutional configurations regulating post-war reconstruction, problematising the weak-state and state-withering theses. Instead, I conceptualised emerging configurations of rule as new state spaces, produced through the mutually transformative encounter between the State and its other(s) and the recalibration of the relationship between them. More specifically, I analysed urban interventions designed to re-organise and re-regulate the city under the rubric of post-war reconstruction. Underlying this pursuit is a broader endeavour to consolidate the socioeconomic gains of the Shii community in Lebanon, project its aggrandisement on the built environment, and reinforce Hizbullah's claim for power in Dahiya. I demonstrated how the intervention was initially undertaken by Hizbullah's quasi-private/quasigovernmental post-war reconstruction agency, Waad, which acted as a locus of power and the institutional entity managing the formation and stewardship of the rules that regulate the public realm.

Adopting a "geographically attuned and scalesensitive approach to state theory,"94 I proposed examining Waad as a 'new state space' manifest in the form of a quasi-private entity that is not the State but which commands significant governance capacity and legitimacy. This sheds light on the fine-tuned workings of governance and power in Dahiya, a political geography seen to be governed not by the State, but by its other(s). Moreover, by examining some of the processual models and diverging visions for the practice and outcome of post-war reconstruction and urban development, I showed how this state space is produced through the uneasy encounter and negotiated collaboration between various actors. In other words, I posit Waad as an assemblage of power and relations and the locus of a regime of rule, which must be understood

is directly accountable to the office of the prime minister. See Irani, George E., and As'ad AbuKhalil (2004), 'Council for Development and Reconstruction (CDR),' Encyclopedia of the Modern Middle East and North Africa, 2nd ed., vol. 1, p. 645 ${ }^{94}$ Brenner (2004), ibid, pp. 2 
as part of a broader and dynamically evolving social whole.

This illustrates how the emergence of new state spaces due to the reconfiguration of the State and its other(s) results in a condition of 'mediated stateness,' and how this condition serves several functions shaped by and shaping contemporary processes of late capitalism and state rescaling; as discussed in what follows:

Firstly, the emergence of new state spaces allows nonstate actors to re-organise and redeploy their resources under the umbrella of politico-institutional configurations sanctioned by the State. Non-state actors do not merely 'capture' the tentacles of the ('weak') State, rather they are profoundly transformed, resulting in their own reconfiguration and redeployment. In Dahiya, Hizbullah associations operating in the fields of education, public health, culture, and public safety reorganised under the umbrella of municipal agencies or were rebranded as civil society 'partners' in governance and development. This partnership between Hizbullahrun municipalities and a global web of faith-based associations in Lebanon and the broader Shii world is reinforced through a combination of partisan and social movement discipline, evocations of Shii piety as a disciplinary force, 95 and neoliberal invocations of the community' as an active participant in its own development. ${ }^{96}$

Secondly, new state spaces generate platforms for the emergence and consolidation of relations between local and global state and non-state actors. While these 'glocal' relations require a stamp of official approval from the State, quasi-private and quasigovernmental configurations permanently blur the fuzzy boundary between the local and the global and replace the State as the only internationally recognised framework and main mediation structure between the two. As is the case in Dahiya, this can assume multiple formal and informal forms of collaboration, including intermunicipal cooperation schemes, development assistance, and supranational religious fraternities.

Thirdly, these new state spaces acquire broad policymaking and enforcement powers. This transfers policy discussions, enactment, and enforcement (prerogatives assumed to be the de jure right of the

\footnotetext{
${ }^{95}$ Marei (2016), ibid

${ }^{96}$ Marei et. al. (2018), ibid
}

State) away from the conventional levels and hierarchies of government and political authority. Instead, committees made up of handpicked, appointed 'experts' design and operationalise far-reaching policy interventions. These committees are typically drawn up by dominant political actors from within the State and from outside it. What is more, these quasiprivate/quasigovernmental configurations are premised on a sense of 'partnership' between the State and sub-/supranational intermediaries and rival sources of power whose authority is not contingent on the (Lebanese) State. Critics of this model of governance frequently question the democratic credentials of these politico-institutional set-ups, arguing that it results in autocratic forms of governance, whereby decisions are crafted outside the scope of democratic institutions and away from the scrutiny of elected watchdogs, the media, and civil society. ${ }^{97}$

As I demonstrated in the analysis of the contentious politics of Hizbullah's post-war urban intervention, the party assigned to two senior officials closely affiliated with its Executive Council the task of drawing up Waad's Consultative Committee. The two officials handpicked the architects and planners who were asked to develop a master plan, detailing what a restored-andimproved Dahiya should look like and which models and processes of urban reconstruction should be deployed. In other words, the different visions for the practice and outcome of post-war reconstruction were negotiated within the framework of the nongovernmental agency and not within the conventional sites of policymaking and political authority. Furthermore, Waad positioned itself as the sole channel of communication between residents, local authorities, and construction contractors. This determined the boundaries of the new state space, the contours and features of which are hard to distinguish and discern. These configurations are not unique to post-2006 Dahiya: they are emblematic of development and urban policymaking and post-war reconstruction in Lebanon since the country re-emerged from its fifteenyear civil war in 1991. In Dahiya, this has emboldened Hizbullah vis-à-vis other stakeholders (including the State and the residents) and consolidated the Shii

\footnotetext{
${ }^{97}$ Swyngedouw, Eric, Frank Moulaert, and Arantxa Rodriguez (2002), 'Neoliberal Urbanization in Europe: LargeScale Urban Development Projects and the New Urban Policy,' Antipode, 34 (3), pp. 542-77
} 
political movement's position as the dominant powerbroker and go-between in the suburbs. ${ }^{98}$

However, the emergence of regimes of governance and rule dominated by Hizbullah should not mislead us into believing that the State in Lebanon is dwindling or that Hizbullah is 'capturing' the State and entrenching its 'state within a state'. Instead, these new state spaces should be understood as the product of the pragmatic encounter between the two, whereby both the State and Hizbullah are reconfigured and rescaled. This is achieved not in spite of the State but precisely because of it. The State provides the legislative scaffolding, the politico-economic environment, and the diplomatic channels that allows for the redistribution of powers and competencies to take place and for mediated stateness to crystallise. These transformations cannot be disaggregated from global transformations occurring under the rubric of globalisation, neo/liberalisation, liberal peace-building, and the maxims of good governance, community empowerment, and publicprivate partnership.

\section{CONCLUSION}

A dominant narrative predicated on tropes of 'state weakness' characterises scholarly and policy analyses of state and of state-society relations in Lebanon. Proponents of this narrative oscillate between the view that the Lebanese state is 'weak' by historical design and the view that it has 'declined' or 'withered away' as a result of neoliberal reforms and the encroachment of sectarian and non-/extra-state actors. This draws on a structuralist understanding of the modern State as an autonomous entity vis-à-vis 'Society'. I part with this understanding and follow instead a postmodernist Foucauldian line of inquiry, recognising "that the [S] tate does not wield power, but [that] power is diffused throughout the social body and reproduced in social relations." ${ }^{99}$ In other words, my analysis takes as its starting point that the State is one of several contingent sites of power. By examining the politics of post-war reconstruction, I interrogated the social and power relations latent in the regimes of governance and rule that emerged in Dahiya in the aftermath of the 2006 war

\footnotetext{
${ }^{98}$ Harb, Mona (1999), 'La reconstruction de la banlieue sudouest de Beyrouth: Une négociation entre État et acteurs politiques,' in Reconstruction et réconciliation au Liban, ed. by Eric Huybrechts and Chawqi Douayhi (Beirut: Cermoc). See also Harb and Fawaz (2010), ibid, and Fawaz (2009; 2014), ibid
}

with Israel. I argued that both the State and its other(s) are transformed, rescaled and reconfigured. Rather than view this reconfiguration as a heterarchic zone of limited statehood and the 'capture' of the tentacles of the State by non-state actors, I view it as the emergence of evolutionary models of governance: new state spaces. In so doing, I make the case for a state analysis not concerned with discerning what the State is or what it ought to be, or driven by a quest to decipher where it begins and where its other(s) end. Instead, I propose an analysis that is concerned with unpacking the real and messy workings of government. I present this inquiry into the politics of governing post-war Dahiya as an empirically informed attempt to address the big questions of state and social theories; not as a relativisation of the weak-state and state-withering theses.

I posit that a new-state-spaces approach has the merit of examining regimes of rule beyond the limitations of state-centric geographical categories and scalar assumptions. These state spaces are new insofar as they are shaped by processes of globalisation and late capitalism. Furthermore, drawing on socialconstructionist notions of space-as-process, such an approach conceives of new state spaces as the product of encounters taking place at and across the fuzzy boundary between seemingly dichotomous categorical imperatives: the State and the non-state, the local and the global, the national and the sub-/ supranational. Therefore, this approach understands regimes of rule in relation to their dynamically evolving social whole, which includes the State, but is not limited to or confined by it. As a consequence, a new-state-spaces approach contributes to an extended understanding of the State, accounting for its complex interactions with its non/ extra-state other(s). Finally, by conceptualising them as new state spaces, I reiterate the importance of probing into the power relations latent in these regimes of governance and rule, the role of violence and force in their emergence and consolidation, and the discursive tools of domination at their disposal; questions at the core of state and social theories.

${ }^{99}$ Mouawad, Jamil, and Hannes Baumann (2017), 'Wayn AlDawla?: Locating the Lebanese State in Social Theory,' Arab Studies Journal, 25 (1), pp. 77 
For practitioners and activists, a new-state-spaces approach is an invitation to develop more robust political analyses, which a) map the actors actually involved in regimes of rule (as opposed to those that ought to be involved), b) examine the modalities of decision-making and the mechanisms of negotiation deployed, and c) question the democratic (or, at least, the inclusionary/exclusionary) credentials of regimes of rule in the context of neoliberal globalisation and late capitalism.

Statehood and a method of translating this improved understanding into a workable tool to practitioners in the field.

\section{POSTSCRIPT}

During the preparation of this article, Lebanon witnessed the outbreak of popular protests and widespread demands for radical change. Since the outbreak of what has been referred to as the 17th of October Revolution, the country's multifaceted crisis has spiralled downhill, bringing the Lebanese political system under increased and perhaps unprecedented scrutiny. Fuelling this uprising is a palpable anger triggered by bad planning and mismanagement, endemic corruption, economic stagnation, unsustainably high public debt and external imbalances, soaring unemployment, and rolling electricity blackouts. These and other factors led to Lebanon's crippling financial collapse, which threatens to pauperise the country's already diminishing middle class. The national-unity government of Prime Minister

\footnotetext{
${ }^{100}$ The cause of the blast is yet undetermined and might never be definitively determined, given Lebanon's track record of bad-faith investigations. Hizbullah's opponents were quick to accuse the group of storing ultra-precision weapons in civilian areas, while others cited the group's alleged long-standing interest in ammonium nitrate, the highly explosive chemical that caused the explosion. For example, the Washington Institute for Near East Policy launched an interactive map of alleged Hizbullah activities around the world. Developed by former FBI counterterrorism expert, Matthew Levitt, the online resource claims to "offer new information" on Hizbullah's global operations, including the acquisition and storage of ammonium nitrate for the production of explosives. See Levitt, Matthew (2020), Lebanese Hezbollah: Select Worldwide Activity Interactive Map and Timeline. (Washington, D.C.: Washington Institute for Near East Policy). Available at: https://www.washingtoninstitute.org/uploads/Documents $\angle$ pubs/LebaneseHezbollahMapEssay.pdf. The resource is
}

Saad Hariri stepped down on the 29th of October 2019, a move which failed to mollify the protesters. The crisis was further exacerbated by the global outbreak of the COVID-19 pandemic as well as several waves of U.S. sanctions designed to maximise pressure on Syria, Iran and their allies, especially the Lebanese Hizbullah. A decision by regional and international governments to boycott the new Lebanese government citing that it is dominated by Hizbullah and its allies, meant that the international community would deny Lebanon the bailout needed to mitigate the impact of its crisis.

If this wasn't enough, a seismic explosion occurred in a warehouse containing highly explosive ammonium nitrates at the Port of Beirut on the 4th of August 2020. The explosion - which is considered to be one of the strongest non-nuclear blasts in history - killed and wounded tens of thousands, displaced some 300,000 people, and destroyed much of the city. ${ }^{100}$ The cataclysmic blast revealed how state institutions are beholden to powerbrokers, purposefully mismanaging them to empower and enrich the ruling few. The cabinet resigned, blaming the blast on "endemic corruption" that is "bigger than the state"101 and warning that the country is "slipping into becoming a failed state."102

At the time of writing, Lebanon is sailing into the teeth of the gale. An investigation into the explosion has thus far yielded no result. Some 350,000 Lebanese citizens have applied for immigration. The Special Tribunal for Lebanon - the first tribunal of international character to prosecute terrorist crimes in times of peace - has implicated a Hizbullah member in the assassination of former Prime Minister, Rafik Hariri, but

widely cited by critics of Hizbullah. Others pointed the finger at the consecutive ministers and customs officials responsible for the Port of Beirut, accusing them of purposefully mismanaging the facility to enrich and empower the ruling few, with little regard to the security and safety of the facility. For example, the Lebanese Aljadeed TV aired a series of provocative programmes and reportages since October 2019, exposing corruption in the Lebanese state and public sector with a particular focus on the Port of Beirut and the Customs Authority. Some of these reportages are available on Aljadeed's website: http://aljadeed.tv.

${ }^{101}$ Lebanon president accepts government resignation after Beirut blast (2020), Aljazeera (10 th of August). Available at: https://www.aljazeera.com/news/2020/08/lebanon-pmhassan-diab-resigns-anger-beirut-blast-200810135202076.htm ${ }^{102}$ Cornish, Chloe (2020), 'Lebanon minister quits and warns of "failed state" risk,' Financial Times (3rd of August). Available at: https://www.ft.com/content/2b4e950a-57bd4ded-819b-f3a20a57d2bb 
exonerated the party's leadership. ${ }^{103}$ And a reconstruction effort undertaken by the World Patriarchal Maronite Foundation for Development, the developmental agency of the Maronite Church, has commenced in the neighbourhoods affected by the blast. The threat of internationalisation and foreign intervention looms as regional and world leaders link promises of assistance with political and diplomatic conditions, insisting that Lebanon must "commit and act for real change"104 and establish "a new political order"105, and warning that "if these reforms are not made, Lebanon will continue to sink."106 Meanwhile, politicians are scrambling to avoid reckoning for the multifaceted crisis, engaging instead in endless bickering over 'shares' in government and public office. Bringing an end to two months without government in a time of national calamity, politicians have finally agreed on nominating a Prime Minister to lead Lebanon out of its crisis, the very same Saad Hariri!

In short, as the country marks the centenary of Greater Lebanon, the colonial antecedent of the modernday Republic of Lebanon, it has become apparent beyond the shadow of a doubt that the current governing system is incapable of extricating the country from its national calamities. Lebanon is facing an inescapable demand for accountability and meaningful systemic change.

\section{ACKNOWLEDGMENTS}

This research is informed by fieldwork carried out in 2015 and 2016 with the support of a research grant awarded by the Arab Council for the Social Sciences (ACSS) and funded by the Swedish International Development Cooperation Agency (SIDA). The completion of this article took part within the context of a project that has received funding from the European Research Council (ERC) under the European Union's Horizon 2020 research and innovation programme (Grant agreement No. 724557).

\footnotetext{
103 Simons, Marlise, and Ben Hubbard (2020), '15 Years After an Assassination Rocked Lebanon, a Trial Ends on a Muted Note,' New York Times (18th of August). Available at: https://www.nytimes.com/2020/08/18/world/middleeast/ hariri-assassination-trial-hague.html

104 Statement of United States Under Secretary of State for Political Affairs David Hale (13 ${ }^{\text {th }}$ of August). Text available at: https://lb.usembassy.gov/us-statement/.

105 Press conference of French President Emmanuel Macron (6 ${ }^{\text {th }}$ of August). Transcript available at:
}

\section{GRATITUDE}

** I would like to extend my gratitude to my friend and colleague, Dr Mona Atia. This research is indebted to the insightful and fruitful exchanges we shared during our sojourns in Morocco and Lebanon. I am also grateful to Dr Mona Fawaz, who provided invaluable insights and graciously encouraged me to pursue this research. Finally, I would like to thank Dr Olaf Bachmann and the participants in the meeting of the African Leadership Centre in Nairobi, Kenya, for providing feedback on the arguments presented in this article.

\section{BIBLIOGRAPHY}

Abdul-Hussain, Hussain (2009), 'Hezbollah: A State Within a State,' Current Trends in Islamist Ideology, 8, pp. 68-81

Aggestam, Karen, et. al. (2009), 'The Arab State and Neoliberal Globalization,' in The Arab State and Neo-Liberal Globalization: The Restructuring of State Power in the Middle East, ed. by Laura Guazzone and Daniela Pioppi (Reading: Ithaca), pp. 325-236

Al-Harithy, Howayda (ed.) (2010), Lessons in Post-War Reconstruction: Case Studies from Lebanon in the Aftermath of the 2006 War. (New York: Routledge)

Alagha, Joseph (2006), The Shifts in Hizbullah's Ideology: Religious Ideology, Political Ideology and Political Program (Amsterdam: Amsterdam University Press)

Atzili, Boaz (2010), 'State Weakness and "Vacuum of Power" in Lebanon,' Studies in Conflict \& Terrorism, 33 (8), pp. 757-782

Ayubi, Nazih (1996), Over-Stating the Arab State: Politics and Society in the Middle East. (New York: I.B. Tauris)

Bachmann, Olaf, Funmi Olonisakin, and Fouad G. Marei (2020), 'Revisiting Governance: Extended Statehood in Africa

https://www.elysee.fr/emmanuelmacron/2020/08/06/liban-conference-de-presse-dupresident-emmanuel-macron-depuis-beyrouth.

${ }^{106}$ Declaration of French President Emmanuel Macron (6 $6^{\text {th }}$ of August). Transcript available at:

https://www.elysee.fr/emmanuelmacron/2020/08/06/declaration-du-president-emmanuelmacron-a-son-arrivee-au-liban-deux-jours-apres-lexplosionau-port-de-beyrouth. 
and Beyond', in Was es (heute) heißt, Soldat zu sein, ed. by Gerhard Kümmel (Baden-Baden: Nomos), pp. 145-169

Bahout, Joseph (2016) The Unraveling of Lebanon's Taif Agreement: Limits of Sect-Based Power Sharing. (Washington, D.C.: Carnegie Endowment for International Peace)

Baumann, Hannes (2017), Citizen Hariri: Lebanon's Neoliberal Reconstruction (New York: Oxford University Press)

Beinin, Joel (2009), 'Neo-Liberal Structural Adjustment, Political Demobilization and Neo-Authoritarianism in Egypt,' in The Arab State and Neo-Liberal Globalization: The Restructuring of State Power in the Middle East, ed. by Laura Guazzone and Daniela Pioppi (Reading: Ithaca), pp. 19-46

Bergh, Sylvia I. (2013), The Redeployment of State Power in the Southern Mediterranean: Implications of Neoliberal Reforms for Local Governance (New York, NY: Routledge), pp. 1-19

Bogaert, Koenraad (2013), 'Contextualizing the Arab Revolts: The Politics behind Three Decades of Neoliberalism in the Arab World,' Middle East Critique, 22 (3), pp. 213-234

Brenner, Neil and Nik Theodore (2002), 'Cities and the Geographies of "Actually Existing Neoliberalism",' Antipode, 34 (3), pp. 349-379

Brenner, Neil. 2004. New State Spaces: Urban Governance and the Rescaling of Statehood (New York: Oxford University Press)

Cammett, Melani (2014a), Compassionate Communalism: Welfare and Sectarianism in Lebanon (Ithaca: Cornell University Press)

Cammett, Melani (2014b), 'Sectarian Politics and Social Welfare: Non-state Provision in Lebanon,' in The Politics of Non-State Welfare, ed. by Melani Cammett and Lauren M. MacLean (Ithaca: Cornell University Press)

Cammett, Melani, and Sukriti Issar (2010), 'Bricks and Mortar Clientelism. Sectarianism and the Logics of Welfare Allocation in Lebanon,' World Politics 62 (3), pp. 381-421 Castells, Manuel (1977 [1972]), The Urban Question: A Marxist Approach (Cambridge: MIT Press)

Chakrabarty, Dipesh (2008 [2000]), Provincializing Europe: Postcolonial Thought and Historical Difference. (Princeton: Princeton University Press).

Cornish, Chloe (2020), 'Lebanon minister quits and warns of "failed state" risk,' Financial Times ( $3^{\text {rd }}$ of August). Available at: https://www.ft.com/ content/2b4e950a-57bd-4ded-819bf3a20a57d2bb

Declaration of French President Emmanuel Macron (6 $6^{\text {th }}$ of August) Transcript available at:

https://www.elysee.fr/emmanuelmacron/2020/08/06/declaration-du-president-emmanuelmacron-a-son-arrivee-au-liban-deux-jours-apres-lexplosionau-port-de-beyrouth.

Early, Bryan R. (2006), 'Larger than a Party yet Smaller than a State: Locating Hezbollah's Place within Lebanon's State and Society,' World Affairs, 168 (3), pp. 115-128

Fakhoury, Tamirace (2014), ‘Debating Lebanon's PowerSharing Model: An Opportunity or an Impasse for Democratization Studies in the Middle East?,' The Arab Studies Journal, 22 (1): pp. 230-255

Fawaz, Leila T. (1983), Merchants and Migrants in Nineteenth Century Beirut (Cambridge: Harvard University Press)

Fawaz, Mona (2009), 'Hezbollah as Urban Planner? Questions to and from Planning Theory,' Planning Theory, 8 (4), pp. 323334

Fawaz, Mona (2014), 'The Politics of Property in Planning: Hezbollah's Reconstruction of Haret Hreik (Beirut, Lebanon) as a Case Study,' International Journal of Urban and Regional Research, 38 (3), pp. 922-934

Fawaz, Mona (2014), 'The Politics of Property in Planning: Hizbullah's Reconstruction of Haret Hreik (Beirut) as Case Study', International Journal of Urban and Regional Research, 38 (3), pp. 922-934

Fayad, Rahif (2010), Min al-'Imāra ilā al-Madìna (From Architecture to Urbanism) (Beirut: Dar Al-Farabi)

Fregonese, Sara (2012), 'Beyond the "Weak State:" Hybrid Sovereignties in Beirut,' Environment and Planning, 30, pp. 655-674

Gates, Caroline (1989), 'The Historical Role of Political Economy in the Development of Modern Lebanon, Papers on Lebanon (Oxford: Centre for Lebanese Studies)

Gates, Caroline (1998), The Merchant Republic of Lebanon: The Rise of an Open Economy (Oxford: Centre for Lebanese Studies)

Ghandour, Marwan, and Mona Fawaz (2010), 'Spatial Erasure: Reconstruction Projects in Beirut,' ArteEast Quarterly. 
Available at: http://arteeast.org/2012/02/05/spatialerasure$\underline{\text { reconstruction-projects-in-beirut }}$

Hamieh, Christine S. and Roger MacGinty (2011),

'Reconstructing Post-2006 Lebanon: A Distorted Market,' in Rethinking the Liberal Peace: External Models and Local Alternatives, ed. by Shahrbanou Tadjbakhsh (New York: Routledge), pp. 181-94

Hamzeh, Ahmad Nizar (2004), In the Path of Hizbullah (New York: Syracuse University Press)

Harb, Mona (1999), ‘La reconstruction de la banlieue sudouest de Beyrouth: Une négociation entre État et acteurs politiques,' in Reconstruction et réconciliation au Liban, ed. by Eric Huybrechts and Chawqi Douayhi (Beirut: Cermoc)

Harb, Mona (2010), Le Hezbollah a Beyrouth: De la banlieue à la ville (Paris: Karthala)

Harb, Mona, and Mona Fawaz (2010), 'Influencing the Politics of Reconstruction in Haret Hreik,' in Lessons in Post-War Reconstruction: Case Studies from Lebanon in the Aftermath of the 2006 War, ed. by Howayda Al-Harithy (New York:

Routledge), pp. 21-45

Harik, Judith Palmer (2004), Hezbollah: The Changing Face of Terrorism (New York: I.B. Tauris)

Harvey, David (1973), Social Justice and the City (Baltimore, MD: Johns Hopkins University Press)

Hashemi, Nader, and Dany Postel, (2017), 'Sectarianization: Mapping the New Politics of the Middle East,' The Review of Faith and International Affairs, 15 (3)

Hazbun, Waleed (2016), 'Assembling Security in a "Weak State:" The Contentious Politics of Plural Governance in Lebanon Since 2005,' Third World Quarterly, 37 (6), pp. $1053-$ 1070

Heydemann, Steven (2007), 'Upgrading Authoritarianism in the Arab World,' Analysis Papers (Washington D.C.: Saban Center for Middle East Policy / Brookings Institution)

Hinnebusch, Raymond (2000), 'Liberalization without Democratization in "Post-Populist" Authoritarian States,' in Citizenship and the State in the Middle East, ed. by Nils Butenschon, Uri Davis and Manuel Hassassian (New York, NY: Syracuse University Press), pp. 123-145
Hinnebusch, Raymond (2006), 'Authoritarian Persistence, Democratization Theory and the Middle East,'

Democratization, 13 (3), pp. 373-395

Hinnebusch, Raymond (2018), 'From Westphalian Failure to Heterarchic Governance in MENA: The Case of Syria,' Small Wars and Insurgencies, 29 (3), pp. 391-413

Hourani, Najib (2013), 'Lebanon: Hybrid Sovereignties and U.S. Foreign Policy,' Middle East Policy, 20 (1), pp. 39-55

Hydén, Göran, Julius Court, and Kenneth Mease (2004), Making Sense of Governance: Empirical Evidence from Sixteen Developing Countries (Boulder: Lynne Rienner)

Irani, George E., and As'ad AbuKhalil (2004), 'Council for Development and Reconstruction (CDR),' Encyclopedia of the Modern Middle East and North Africa, 2nd ed., vol. 1, pp. 645

Ismail, Salwa (2006), Political Life in Cairo's New Quarters: Encountering the Everyday State (Minneapolis: University of Minnesota Press)

Jha, Praveen (2005). 'Withering Commitments and Weakening Progress: State and Education in the Era of Neoliberal Reforms,' Economic and Political Weekly, 40 (33), pp. 3677-3684

Johnson, Michael (1986), Class and Client in Beirut: The Sunni Muslim Community and the Lebanese State (Reading: Ithaca) Kamrava, Mehran (2014), 'Weak States in the Middle East,' in Fragile Politics: Weak States in the Greater Middle East, ed. by Mehran Kamrava (London: Hurst)

Kasfir, Nelson, Georg Frerks and Niels Terpstra (2017), 'Introduction: Armed Groups and Multi-Layered Governance,' Civil Wars, 19 (3), pp. 257-278

Khalaf, Samir (1977), 'Changing forms of political patronage in Lebanon,' in Patrons and Clients in Mediterranean Societies, ed. by Ernest Gellner and John Waterbury (London: Duckworth), pp. 185-205

Kindt, Michael T. (2009), 'Hezbollah: A State within a State,' in The World's Most Threatening Terrorist Networks and Criminal Gangs, ed. by Michael T. Kindt, Jerrold M. Post, and Barry R. Schneider (New York: Palgrave Macmillan)

Krinjnen, Marieke, and Mona Fawaz (2010), 'Exception as the Rule: High-End Developments in Neoliberal Beirut,' Built Environment, 36 (2), pp. 245-259 
Lebanon president accepts government resignation after Beirut blast (2020), Aljazeera (10 ${ }^{\text {th }}$ of August). Available at: https:/ / www.aljazeera.com/news/2020/08/lebanon-pmhassan-diab-resigns-anger-beirut-blast-200810135202076.html

Leenders, Reinoud (2012), Spoils of Truce: Corruption and StateBuilding in Postwar Lebanon (Ithaca: Cornell University Press)

Lefebvre, Henri (1991 [1974]), The Production of Space (Cambridge: Blackwell)

Levitt, Matthew (2020), Lebanese Hezbollah: Select Worldwide Activity Interactive Map and Timeline. (Washington, D.C.: Washington Institute for Near East Policy). Available at: https://www.washingtoninstitute.org/uploads/Documents Lpubs/LebaneseHezbollahMapEssay.pdf

Lobao, Linda, et. al. (2018), 'The Shrinking State? Understanding the Assault on the Public Sector,' Cambridge Journal of Regions, Economy and Society, 11 (3), pp. 389-408

Lund, Christian (2006), 'Twilight Institutions: An Introduction,' Development and Change, 37 (4), pp. 673-684

Makdisi, Samir, and Marcus Marktanner (2009), 'Trapped by Consociationalism: The Case of Lebanon,' Topics in Middle Eastern and North African Economies, 11, pp. 1-15

Malaeb, Bilal (2018), State Fragility in Lebanon: Proximate Causes and Sources of Resilience (London/Oxford: LSE-Oxford Commission on State Fragility, Growth and Development)

Malsagne, Stéphane (2011), Fouad Chéhab: Une figure oubliée de l'histoire libanaise (Paris: Karthala)

Mann, Michael (1984), "The Autonomous Power of the State: Its Origins, Mechanisms and Results," European Journal of Sociology, 25 (2), 185-213

Mansour, Imad (2017), 'The State of Hezbollah? Sovereignty as a Potentiality in Global South Contexts,' in The Oxford Encyclopedia of Empirical International Relations Theory, ed. by William R. Thompson (New York: Oxford University Press), Vol. 3, pp. 433-454

Marei, Fouad Gehad (2016), 'Preaching Development: Shi'i Piety and Neoliberalism in Beirut', in Religious Activism in the Global Economy, ed. by Sabine Dreher and Peter J. Smith (Washington D.C.: Rowan and Littlefield), pp. 167-187

Marei, Fouad Gehad (2019), Are Municipalities in Lebanon Delivering? Survey Results on Solid Waste Management, Public
Safety and Government Transparency (Berlin: Democracy Reporting International)

Marei, Fouad Gehad (2020), 'Dahiya Doctrine', in Conflict in the Modern Middle East: An Encyclopaedia of Civil War, Revolutions and Regime Change, ed. by Jonathan K. Zartman (Santa Barbara: ABC-CLIO)

Marei, Fouad Gehad, et. al. (2018) 'Interventions on the Politics of Governing the "Ungovernable", Political Geography, 67, pp. 181

May, Samantha (2019), 'The Rise of the "Resistance Axis": Hezbollah and the Legacy of the Taif Agreement,' Nationalism and Ethnic Politics, 25 (1), pp. 115-132

Menkhaus, Ken (2006), 'Governance without Government in Somalia: Spoilers, State Building, and the Politics of Coping,' International Security, 41 (3), pp. 74-106

Mervin, Sabrina (2008), Hezbollah: État des lieux (Paris: Actes Sud).

Meyerson, Martin (1968), 'Urban Policy: Reforming Reform,' Daedalus, 97 (4), pp. 1410-1430

Migdal, Joel (1988), Strong Societies and Weak States: StateSociety Relations and State Capabilities in the Third World (Princeton: Princeton University Press); and Migdal, Joel (2001), State in Society: Studying How States and Societies Transform and Constitute One Another (New York: Cambridge University Press), pp. 48-49

Monroe, Kristin V. (2016), The Insecure City: State, Power and Mobility in Beirut (New Brunswick: Rutgers University Press)

Mouawad, Jamil, and Hannes Baumann (2017), 'Wayn AlDawla?: Locating the Lebanese State in Social Theory,' Arab Studies Journal, 25 (1), pp. 66-90

Nagle, John (2016), 'Between Entrenchment, Reform and Transformation: Ethnicity and Lebanon's Consociational Democracy,' Democratization, 23 (7), pp. 1144-1161

Nagle, John and Mary-Alice Clancy (2019), 'Power-Sharing After Civil War: Thirty Years Since Lebanon's Taif Agreement,' Nationalism and Ethnic Politics, 25 (1)

Nassar, Adib (2018), 'Hezbollah is a State Above the State,' The Arab Weekly (9 $9^{\text {th }}$ of September)

Nauclér, Elisabeth (2005), 'Autonomy and Multilevel Governance: Experiences in Nordic and Continental European Cooperation,' in Autonomy, Self-Governance and 
Conflict Resolution: Innovative Approaches to Institutional Design in Divided Societies,' ed. by Marc Weller and Steffan Wolff (New York, NY: Routledge), pp. 85-100

Noe, Nicholas (ed.) (2007), Voice of Hezbollah: The Statements of Sayyed Hassan Nasrallah (New York: Verso)

Nucho, Joanne Randa (2016), Everyday Sectarianism in Urban Lebanon: Infrastructures, Public Services, and Power (Princeton: Princeton University Press)

Ponzini, Davide, and Michele Nastasi (2017), Starchitecture: Scenes, Actors, and Spectacles in Contemporary Cities (New York: Monacelli Press).

Press conference of French President Emmanuel Macron (6 $6^{\text {th }}$ of August). Transcript available at:

https://www.elysee.fr/emmanuelmacron/2020/08/06/liban-conference-de-presse-dupresident-emmanuel-macron-depuis-beyrouth

Qassem, Naim (2005), Hizbullah: A Story from Within (London: Saqi).

Radice, Hugo (2008), 'The Developmental State under Global Neoliberalism,' Third World Quarterly, 29 (6), pp. 1153-1174

Reagan, Ronald (1981), 'President Ronald Reagan's Inaugural Address at the United States Capitol, 1/20/1981,' Records of the White House Communications Agency (WHCA). Available from the National Archives Catalogue (Identifier: 7087567), https://catalog.archives.gov/id/7087567

Richmond, Oliver P. (2005), The Transformation of Peace. (London: Palgrave)

Richmond, Oliver P. (2006), 'The problem of peace: understanding the 'liberal peace', 'Conflict, Security $\mathcal{E}$ Development, 6 (3), pp. 291-314

Saad-Ghorayeb, Amal (2002), Hizbu'llah: Politics and Religion (London: Pluto Press)

Salibi, Kamal (1966), 'Lebanon under Fuad Chehab 19581964,' Middle Eastern Studies, 2 (3), pp. 211-226

Salibi, Kamal (2003), A House of Many Mansions: The History of Lebanon Reconsidered (New York: I.B. Tauris)

Schmid, Heiko (2002) 'The Reconstruction of Downtown Beirut in the Context of Political Geography,' The Arab World Geographer, 5 (4), pp. 232-248
Sharara, Waddah (1998), Dawlat Hizballah: Lubnan Mujtama'an Islamiyyan (The State of Hizbullah: Lebanon, an Islamic Society) (Beirut: Dar al-Nahar)

Shidyaq, Imad (2007), al-Muqāwamah wa-sayyiduhā Hasan Nașr Allāh (The Resistance and its Master: Hassan Nasrallah) (Beirut: al-Maktaba al-Hadìtha)

Simons, Marlise, and Ben Hubbard (2020), '15 Years After an Assassination Rocked Lebanon, a Trial Ends on a Muted Note,' New York Times (18 ${ }^{\text {th }}$ of August). Available at: https://www.nytimes.com/2020/08/18/world/middleeast/ hariri-assassination-trial-hague.html.

Soja, Edward W. (1980), 'The socio-spatial dialectic,' Annals of the Association of American Geographers, 70, pp. 207-255

Statement of United States Under Secretary of State for Political Affairs David Hale (13 $3^{\text {th }}$ of August). Text available at: https://lb.usembassy.gov/us-statement/

Stel, Nora (2016), 'Languages of Stateness in South Lebanon's Palestinian Gatherings: The PLO's Popular Committees as Twilight Institutions,' Development and Change, 47 (3), pp. 449471

Stel, Nora (2020), Hybrid Political Order and the Politics of Uncertainty: Refugee Governance in Lebanon (New York, NY: Routledge)

Stokes, Jamie (ed.), Encyclopedia of the Peoples of Africa and the Middle East (New York: Facts on File. An Imprint of Infobase), pp. $446-447$

Swyngedouw, Eric, Frank Moulaert, and Arantxa Rodriguez (2002), 'Neoliberal Urbanization in Europe: Large-Scale Urban Development Projects and the New Urban Policy,' Antipode, 34 (3), pp. 542-77

Thatcher, Margaret (1987), 'No Such Thing as "Society:" Interview with Douglas Keay,' Woman's Own (23 rd of September). Available at:

http://www.margaretthatcher.org/document/106689, pp. 30

The Fund for Peace (2015), Fragile States Index 2015.

(Washington D.C.: The Fund for Peace)

Tonta, Rachela (2009), 'Why the Chehabist State Failed: The State-in-Society Approach,' Hemispheres: Studies on Cultures and Societies, 24, pp. 91-104 
Verdeil, Éric (2001), 'Reconstructions Manquées à Beyrouth: La poursuite de la guerre par le project urbain,' Annales de la recherché urbaine-Villes et guerres, 91, pp. 65-73

Weber, Max (2004 [1919]), The Vocation Lectures

(Indianapolis: Hackett Publishing).

\section{AUTHOR'S INTERVIEWS}

Al-Khansa, Mohammad Said. Mayor of Ghobeiri. Author's interview (Beirut: 30th September 2014)

Fadlallah, Hussein. Al-Nizam min Al-Iman Campaign

Coordinator. Author's interview (Beirut: 15th April 2010)

Fawaz, Mona. Professor of Urban Studies and Planning at the American University of Beirut, and political activist and cofounder of Beirut Madinati. Author's interview (Beirut: 13 ${ }^{\text {th }}$ November 2015)

Fayad, Rahif. Former president of the Organisation of Arab Architects and chairman of Waad's Consultative Committee. Author's interview (Beirut: 15 th December 2015)

Hatoun, Ahmad. Deputy Mayor of Haret Hreik. Author's interview (Beirut: 30th September 2014)

Jamal, Sany. CEO of Jamal Architects and Engineers and a member of Waad's Consultative Committee. Author's interview (Beirut: 28 $8^{\text {th }}$ December 2015)

Jeshi, Hassan. Managing Director of Waad for

Reconstruction. Author's interview (Beirut: 3rd March 2010)

Kassardjian, Marie-Helène. Responsible Officer for ART GOLD Beirut Southern Suburbs, UNDP. Author's interview (Beirut: 13 th April 2016)

Makki, Mounir. Director of Waad's Liaison Office for Residents' Affairs. Author's interview (Beirut: 28 ${ }^{\text {th }}$ November 2015) 